\title{
DNA Damage Responses in Prokaryotes: Regulating Gene Expression, Modulating Growth Patterns, and Manipulating Replication Forks
}

\author{
Kenneth N. Kreuzer \\ Department of Biochemistry, Duke University Medical Center, Durham, North Carolina 27710 \\ Correspondence: kenneth.kreuzer@duke.edu
}

\begin{abstract}
Recent advances in the area of bacterial DNA damage responses are reviewed here. The SOS pathway is still the major paradigm of bacterial DNA damage response, and recent studies have clarified the mechanisms of SOS induction and key physiological roles of SOS including a very major role in genetic exchange and variation. When considering diverse bacteria, it is clear that SOS is not a uniform pathway with one purpose, but rather a platform that has evolved for differing functions in different bacteria. Relating in part to the SOS response, the field has uncovered multiple apparent cell-cycle checkpoints that assist cell survival after DNA damage and remarkable pathways that induce programmed cell death in bacteria. Bacterial DNA damage responses are also much broader than SOS, and several important examples of LexA-independent regulation will be reviewed. Finally, some recent advances that relate to the replication and repair of damaged DNA will be summarized.
\end{abstract}

Since the publication of DNA Repair and Sutagenesis in 2006 (Friedberg et al. 2006), our understanding of bacterial DNA damage responses has progressed significantly. Some studies have refined known pathways and filled in important details, whereas other studies have uncovered surprising new pathways such as bacterial programmed cell death and a form of replicative repair that reconstitutes severely shattered genomes. This review will focus on these recent advances, with only limited discussion and citation to work that precedes the 2006 tome.

\section{THE SOS RESPONSE}

As scientists have studied the SOS response in Escherichia coli and other bacteria over the last decade, our understanding of SOS has changed in unexpected ways and the pathway has been found integrated in diverse cellular processes. Our understanding of the mechanism of SOS induction has also advanced in recent years, including a view of induction at the single-cell level. A surprising finding is that the functions of the SOS pathway are not uniform between bacterial species, and so the view of SOS as

Editors: Errol C. Friedberg, Stephen J. Elledge, Alan R. Lehmann, Tomas Lindahl, and Marco Muzi-Falconi

Additional Perspectives on DNA Repair, Mutagenesis, and Other Responses to DNA Damage available at http://www.cshperspectives.org

Copyright (C) 2013 Cold Spring Harbor Laboratory Press; all rights reserved; doi: 10.1101/cshperspect.a012674

Cite this article as Cold Spring Harb Perspect Biol 2013;5:a012674 
K.N. Kreuzer

purely a DNA damage response pathway is insufficient. Furthermore, SOS is not the major DNA damage response pathway in some bacterial species (see "SOS-Independent DNA Damage Responses" below). From a practical viewpoint, recent findings also uncover clinical significance of the SOS pathway in the response to diverse antibiotics and also in the spread of virulence and drug-resistance genes. The reader is referred to several excellent recent reviews on various aspects of the SOS response (Michel 2005; Aertsen and Michiels 2006; Kelley 2006; Erill et al. 2007; Butala et al. 2009; Ayora et al. 2011) and to Fuchs and Fujii (2013) on bacterial translesion synthesis (TLS) polymerases for a discussion of this aspect of the SOS response.

\section{SOS Response in E. coli}

\section{The Basic Circuitry of the SOS Response}

The SOS response in E. coli coordinates the cells response to DNA damage by the action of the LexA repressor (Fig. 1) (for review, see Friedberg et al. 2006, and above-cited reviews). LexA pro- tein in its native state binds to the promoter region of multiple SOS genes during normal growth limiting their expression levels. Upon DNA damage, the RecA protein is activated to become a coprotease by formation of a filament of RecA on single-stranded DNA (ssDNA), which facilitates the self-cleavage reaction of LexA. Thus, as LexA repressor levels decrease, expression levels of SOS regulon genes increase. The products of SOS regulon genes are involved in specific DNA repair mechanisms, tolerance of DNA damage, and induced delay of the cell cycle.

LexA also regulates transcription of both its own gene and the recA gene, which is important for the overall function of the circuit. Increased RecA protein levels after DNA damage promotes recombinational repair and effective cleavage of LexA, whereas increased LexA expression allows the SOS response to be rapidly shut off when the inducing signal of ssDNA wanes. Activated RecA protein also serves as coprotease for the bacteriophage $\lambda$ repressor and for UmuD, an E. coli protein involved in DNA damage tolerance and TLS (as well as homologs of both proteins).

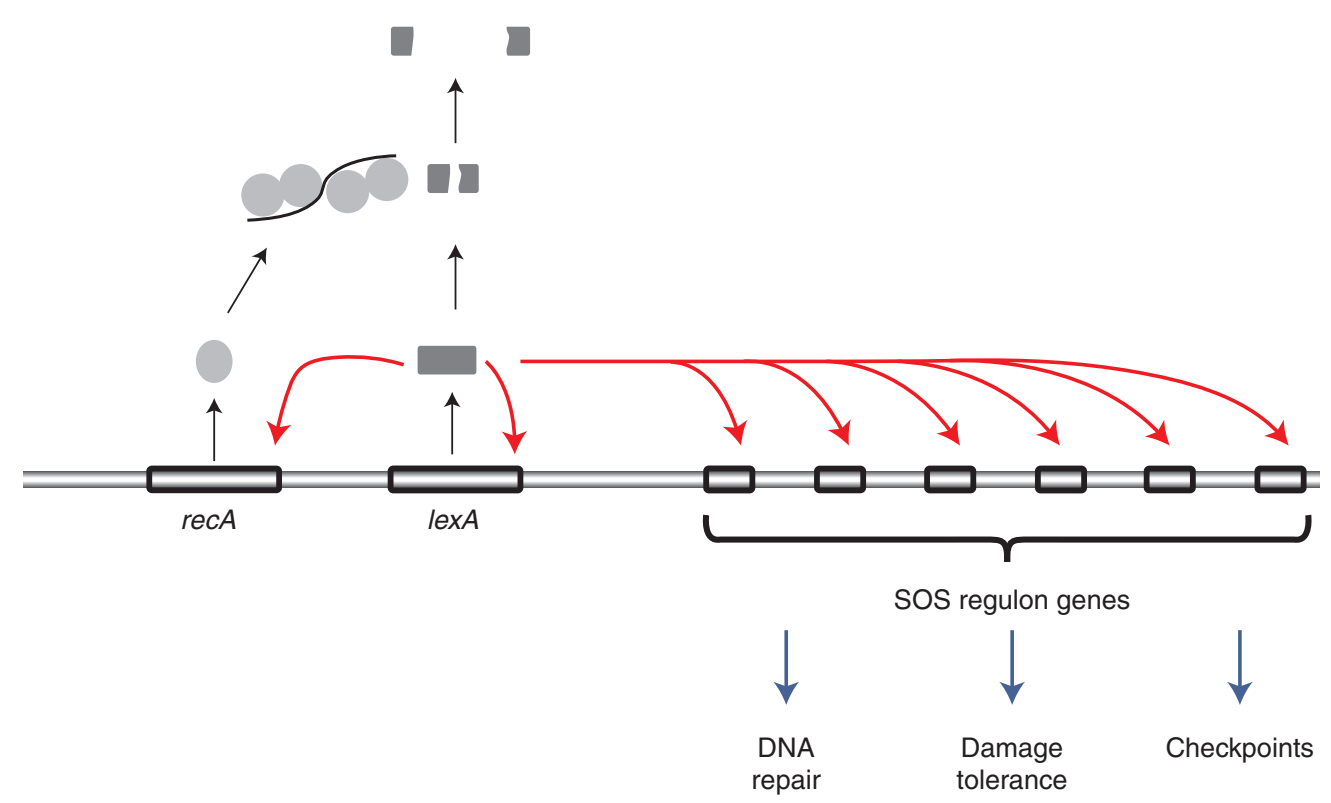

Figure 1. The E. coli SOS response. The basic circuitry of the E. coli SOS response is summarized. RecA proteinDNA filaments serve as a coprotease to activate self-cleavage of the LexA protein, the global repressor of SOS. As described in the text, RecA can also activate self-cleavage of UmuD and the phage $\lambda$ repressor. 
Genome-scale approaches have refined our knowledge of the E. coli genes induced by DNA damage in both SOS-dependent and -independent modes (reviewed by Michel 2005; Kelley 2006; Friedberg et al. 2006). Microarray studies revealed SOS-inducible genes that were largely expected from prior genetic and molecular studies in E. coli (Courcelle et al. 2001; Zheng et al. 2001; Khil and Camerini-Otero 2002). Furthermore, a chromatin immunoprecipitation (ChIP) on chip study confirmed 25 expected LexA binding sites, and also uncovered five new sites with a LexA consensus sequence and 19 apparent LexA binding sites without any obvious LexA motif (Wade et al. 2005).

As described in detail by Friedberg et al. (2006), some genes of the E. coli SOS pathway, such as sulA and umuDC, are induced only late and/or with high levels of DNA damage. The molecular explanation is that increasing levels of DNA damage leads to progressively increasing RecA-promoted LexA proteolysis and thus decreasing LexA concentrations. Thus, a relatively high level of DNA damage is necessary to achieve the very low LexA concentrations that allow induction of genes such as sulA and $u m u D C$, with their very strong LexA binding sites. This arrangement allows the SOS response to be graded, for example, facilitating DNA repair without blocking cell division or inducing TLS polymerase activity at low levels of DNA damage.

\section{How Exactly Is SOS Induced?}

Recent studies have brought significant molecular detail to our understanding of how the SOS response is induced after DNA damage. Biochemical analyses showed that only the DNAfree form of LexA is cleaved by activated RecA protein (Butala et al. 2011). This study has implications that relate the relative strength of LexA binding sites to the sequential order of induction of genes during the damage response. Using substitution mutants of RecA, Gruenig et al. (2008) provided evidence that RecA filament formation, but not ATPase activity, are needed for RecA-induced LexA cleavage. Also relevant to the induction mechanism, muta- tional analyses of RecA filament surface residues defined a discrete LexA binding region (Adikesavan et al. 2011).

Bulk approaches for studying SOS induction have limitations, including the inability to assess whether all cells in a population induce the pathway similarly. Additional insight can be obtained at the single-cell level, using fusion constructs in which the green fluorescent protein (GFP) fluorescent reporter is coupled to either an SOS-inducible promoter or to the RecA protein itself. One new insight obtained from this approach relates to the subcellular localization of recombination proteins. Prior studies in eukaryotic cells revealed DNA damage-induced recombination protein foci in cell nuclei, which were implicated as recombinational repair factories (Lisby et al. 2001; for review, see Lisby and Rothstein 2009). Similar structures were discovered in E. coli using a RecA-GFP fusion allele (Renzette et al. 2005). These investigators found that normal undamaged E. coli cells often displayed one or even multiple foci, about half of which were inferred to contain DNA (based on sensitivity to DAPI [4',6-diamidino-2-phenylindole] treatment) and half not (presumed to be RecA storage structures). A RecA substitution mutant that does not form storage structures in vitro but is otherwise normal (Eldin et al. 2000) provided a simpler tool because a GFP fusion to this mutant RecA showed only DNA-containing (DAPIsensitive) foci (Renzette et al. 2005). Importantly, DNA damage induced by UV treatment led to an increased number of foci, and the foci relocalized to a position near the cell center. The new position at cell center was proposed to coincide with the sites of replication machinery, arguing that the recombination foci were actively involved in dealing with DNA damage at the replication fork (see "Prokaryotic Strategies for Replicating Damaged DNA" below).

A second important insight emerged by analyzing the time course of induction of GFP fused to SOS promoters. Friedman et al. (2005) showed cascading waves of SOS induction in single cells during a post-UV incubation period. These waves were not previously detected in bulk cultures because of asynchrony between 
K.N. Kreuzer

individual cells in a population. The investigators speculate that resumption of DNA replication may cause one of the later waves, and presented evidence that UmuD cleavage plays an important regulatory role (see discussion of checkpoint function of UmuDC in "Bacterial Damage Response Checkpoints" below). A quantitative analysis of the dynamics and mathematical modeling of the cascading waves of induction was provided in the later work of Shimoni et al. (2009).

\section{DNA Damage Is Not the Only Inducer}

A much broader array of conditions, well beyond DNA damage and replication fork failure, have been shown capable of inducing the SOS response. One natural situation that can induce SOS is the introduction of ssDNA into a recipient cell during a conjugation event (Bailone et al. 1988; Golub and Panzer 1988; Bagdasarian et al. 1992; Petrova et al. 2009; Baharoglu et al. 2010). Indeed, many plasmids encode proteins that bind and inhibit RecA to prevent SOS induction during conjugation, such as the PsiB protein of $F$ plasmid. As already discussed by Friedberg et al. (2006), certain $\beta$-lactam antibiotics that inhibit cell-wall synthesis can also induce SOS in E. coli, but via a distinct pathway involving the DpiBA two-component system (Miller et al. 2003, 2004; also see Aertsen and Michiels 2006; Maiques et al. 2006). Induction by a broad array of antibiotics and the very act of conjugation has important implications for spread of antibiotic resistance and virulence genes (see "A Broader View of the Physiology and Consequences of the SOS Response" below).

\section{Nature of Spontaneous SOS in Untreated Cells}

The single-cell approach has also been useful for analyzing the low level of SOS expression that can be detected in untreated cells. McCool et al. (2004) fused a GFP fluorescent reporter to the sulA gene promoter and analyzed SOS induction in single cells by fluorescence microscopy. Untreated wild-type cells showed a small fraction of cells with significant levels of SOS induc- tion, showing that the overall low level of SOS was caused by a small subset of induced cells that had apparently suffered some kind of spontaneous DNA damage (McCool et al. 2004). Interestingly, the same pattern held for various mutants that had been classified as partially constitutive for SOS (e.g., priA, uvrD, dam, and $r n h A$ ) - each of these showed a larger subpopulation of cells that were induced rather than a uniform level of induction in all cells. Pennington and Rosenberg (2007) continued the analysis of untreated wild-type cells and found that the fraction of induced cells was significantly lower than expected from previous studies; they attributed SOS induction to cells that suffer double-strand break (DSB) formation during the process of DNA replication (Pennington and Rosenberg 2007).

The graded response of SOS genes to LexA concentrations was noted above. The same kind of gradation has now been observed in singlecell studies of spontaneous SOS induction in E. coli. GFP fusions to the recA or lexA promoters resulted in more than $1 \%$ of cells showing spontaneous induction, whereas $<0.1 \%$ of cells with an $u m u D C$ fusion were induced (Kamenšek et al. 2010). Thus, the severity of the DNA damage in those few unfortunate cells that require SOS induction apparently varies greatly, with a small subset apparently suffering fairly catastrophic levels of damage. It will be very interesting to figure out what kind of damages lead to the two (or perhaps more) different induction states.

\section{Diversity in the SOS Response}

between Bacterial Species

\section{Diversity in the SOS Circuit}

Interesting surprises have arisen from studies of SOS in diverse bacteria. The genes induced by the SOS response in bacteria including Bacillus subtilis, Staphylococcus aureus, and Pseudomonas aeruginosa, analyzed with global approaches, show significant overlap but some divergence from those induced in E. coli (Courcelle et al. 2001; Au et al. 2005; Cirz et al. 2006, 2007; Goranov et al. 2006). There is diversity even considering genes whose products are involved 
in DNA damage repair or tolerance, and only a small subset of the E. coli SOS-inducible genes are also in the B. subtilis SOS regulon. Thus, the precise functions of SOS-induced genes appear to be fine-tuned to the biology of the organism. Erill et al. (2007) discusses the evolution of the SOS system in detail.

Additional distinctions from the classical E. coli system support the view that the SOS system is fine-tuned to the biological system. First, in E. coli, LexA acts solely as a repressor protein, inhibiting gene expression in its uncleaved state. Several examples of positive regulation by LexA have now been identified in diverse bacterial species (Tapias et al. 2002; Gutekunst et al. 2005; Jochmann et al. 2009; Smollett et al. 2012). Second, the Mycobacterium tuberculosis LexA protein binds to the regulatory region of two genes encoding small RNAs (Smollett et al. 2012). Third, unlike in E. coli, aminoglycosides, tetracycline, and chloramphenicol all induce SOS in Vibrio cholerae (Baharoglu and Mazel 2011).

Although older literature suggested that Neisseria gonorrhea lacks an SOS system (Black et al. 1998; Davidsen and Tønjum 2006), Schook et al. (2011) recently identified a LexA homolog encoded by gene ng1427. This LexA homolog regulates DNA repair ( $\mathrm{RecN}$, in particular) and can apparently be cleaved by RecA. Interestingly, the response is derepressed by reactive oxygen, possibly via a direct oxidation/ reduction cycle, and so the induction pathway appears to be novel.

\section{RecA Focus Formation Depends on DNA Replication in B. subtilis}

The relationship of DNA damage, RecA foci, and SOS induction was explored in B. subtilis (Simmons et al. 2007; Simmons et al. 2009; for review, see Ayora et al. 2011). RecA focus formation was shown to be dependent on DNA replication, even when the inducing lesion was a DSB. Focus formation did not require the induction of RecA protein levels, so redistribution of existing protein was apparently sufficient. Focus formation was also clearly distinguished from SOS in this system because either ionizing radiation or direct DSB induction led to foci in virtually every cell, but only a small subset of the cells were found to be induced for SOS (Simmons et al. 2009). In contrast, ionizing radiation induces foci formation in virtually every E. coli cell. These results parallel sensitivity results because SOS-noninducible E. coli are hypersensitive to ionizing radiation, but noninducible $B$. subtilis are unaffected. From all of these results, it is clear that B. subtilis has substantial and efficient repair pathways without SOS induction, and that RecA focus formation is mechanistically distinct from SOS induction (also see Centore et al. 2008; Massoni et al. 2012).

\section{A Broader View of the Physiology and Consequences of the SOS Response}

The SOS response is now recognized to play a major role in the generation and spread of antibiotic resistance and other clinically relevant events in bacteria, and is clearly an important factor in evolution of bacterial species and species variants. As reviewed by Kelley (2006) and Erill et al. (2007), subinhibitory levels of antibiotics can induce SOS leading to horizontal gene transfer, spread of antibiotic resistance, and induction of virulence factors.

\section{SOS and Horizontal Gene Transfer}

The role of SOS in horizontal gene transfer is widespread and quite remarkable. Starting with the classic example of phage $\lambda$, it has long been known that SOS induction results in reactivation of many lysogenic prophages, contributing to the spread of prophage-borne genes including virulence genes (see Friedberg et al. 2006; Goerke et al. 2006; Kelley 2006). One of the most dramatic examples of the impact of SOS-inducible phages involves a $V$. cholerae prophage that encodes cholera toxin; SOS induction of phage CTX $\phi$ greatly augments toxin production/release and leads to dissemination of the prophage (Quinones et al. 2005; Waldor and Friedman 2005).

In a parallel fashion, SOS has now been shown to activate conjugative transposons, also called integrative conjugative elements (ICEs). 
On induction, ICEs efficiently transfer from donor to recipient cells, sometimes of different species, carrying genes for antibiotic resistance, pathogenesis, alternative carbon metabolism, and symbiotic relationships (depending on the element; Wozniak and Waldor 2010). Although multiple induction mechanisms exist, the SOS response has been shown to induce ICEs including the SXT element of $V$. cholera (Beaber et al. 2004), the ECEBs1 element of B. subtilis (Auchtung et al. 2005), enteric IncJ elements (McGrath et al. 2005), ICESt1 and ICESt3 from Streptococcus thermophiles (Bellanger et al. 2007, 2008), and probably the RD2 element found in group A Streptococcus (Sitkiewicz et al. 2011).

The widespread role of SOS in horizontal gene transfer is also confirmed by its effects on pathogenicity islands. For example, S. aureus island SaPIbov1 excises and replicates on SOS activation of coresident prophages, which can then package the island into phage-like particles at high efficiency (Ubeda et al. 2005; Ubeda et al. 2007; Tormo et al. 2008). The pathway was shown to work with multiple pathogenicity islands, and clinical strains showed the same phenomenon with resident prophages and islands.

\section{SOS and Antibiotic Resistance}

SOS contributes to antibiotic resistance not just by stimulating gene transfer events, but also by inducing mutation and genomic rearrangements (also see a review on TLS polymerases by Fuchs and Fujii 2013). For example, Cirz et al. (2007) showed that the generation of antibiotic resistance in $S$. aureus in vitro required the SOS response and proposed that up-regulation of the tricarboxylic acid cycle and mutagenic TLS polymerases was involved (also see Kohanski et al. 2010).

Generation of antibiotic resistance from SOS can also result from induction of recombination events. In one prominent example, SOS induction was shown to induce expression of integrase recombination protein that rearranges integrons, thereby activating previously silent cassette genes including those encoding antibiotic resistance proteins (Guerin et al. 2009).
This is a potent mechanism for generation of antibiotic resistance in response to drug treatments, and also as a result of transient SOS induction in response to incoming ssDNA during conjugation or transformation (Baharoglu et al. 2010, 2012). Indeed, this molecular mechanism has been documented to contribute to resistance in a clinical setting. A strain of $P$. aeruginosa highly resistant to a third-generation cephalosporin emerged in a hospital patient at the University of Washington, and the strain went on to become epidemic within the hospital (Hocquet et al. 2012). The original patient had been previously treated with cephalosporin and metronidazole, and these investigators showed that the latter drug induces SOS. In turn, SOS induction in this organism activates the integrase IntI1, which apparently led to the cassette rearrangement that activated high-level expression of the $\beta$-lactamase.

A related concern is that SOS induction has now been shown to directly up-regulate the expression of certain antibiotic resistance genes (Da Re et al. 2009; Wang et al. 2009). The widespread plasmid-borne qnr genes encode proteins that provide resistance to the quinolones by direct binding to the quinolone target DNA gyrase. The qnrB2 gene from a Salmonella enterica integron, along with other qnrB genes, have been shown to be under SOS control, with a conserved LexA binding site in their promoters (Da Re et al. 2009; Wang et al. 2009). Quinolones are potent inducers of SOS, and therefore this regulation mechanism can be directly detrimental to antibiotic therapy.

\section{SOS and Bacterial Pathogenesis}

As reviewed by Kelley (2006) and Erill et al. (2007), SOS also plays a direct role in bacterial pathogenesis because certain virulence genes in diverse bacteria are part of the SOS regulon. This creates a perilous situation in which either treatment with antibiotics or even the natural defense mechanisms of the host can induce virulence factor production in the pathogen (also see a recent study on role of SOS during entry of uropathogenic E. coli in a mouse model in $\mathrm{Li}$ et al. 2010). 
DNA Damage Responses in Prokaryotes

\section{CHECKPOINTS AND PERSISTERS AND APOPTOSIS, OH MY!}

DNA damage responses including SOS are also tightly connected to cell growth inhibition and cell death events, and these also have profound implications for antibiotic action. Studies in the last several years have uncovered surprising complexities including striking modulations in cell growth and death pathways that impact survival after DNA damage and antibiotic treatments (Fig. 2).

\section{Bacterial Damage Response Checkpoints SulA and Cell Division Checkpoints}

It has long been appreciated that SOS induction of the E. coli SulA protein causes a cell-cycle checkpoint by inhibiting cell division, acting at the level of FtsZ polymerization, and thereby providing the cell more time to repair DNA damage (see Friedberg et al. 2006). Recent evidence suggests that the SulA checkpoint in E. coli may be augmented by other checkpoint mechanisms (see below).

A cell-cycle checkpoint that acts directly on the cell division process, but in a manner distinct from SulA has been uncovered in Caulobacter crescentus, which has a eukaryotic-like cell cycle. DNA damage in this bacteria leads to an SOS response that includes the 29-amino acid SidA protein, which inhibits cell division by interacting with the FtsW/FtsN proteins and preventing final cytokinetic ring constriction (Modell et al. 2011).

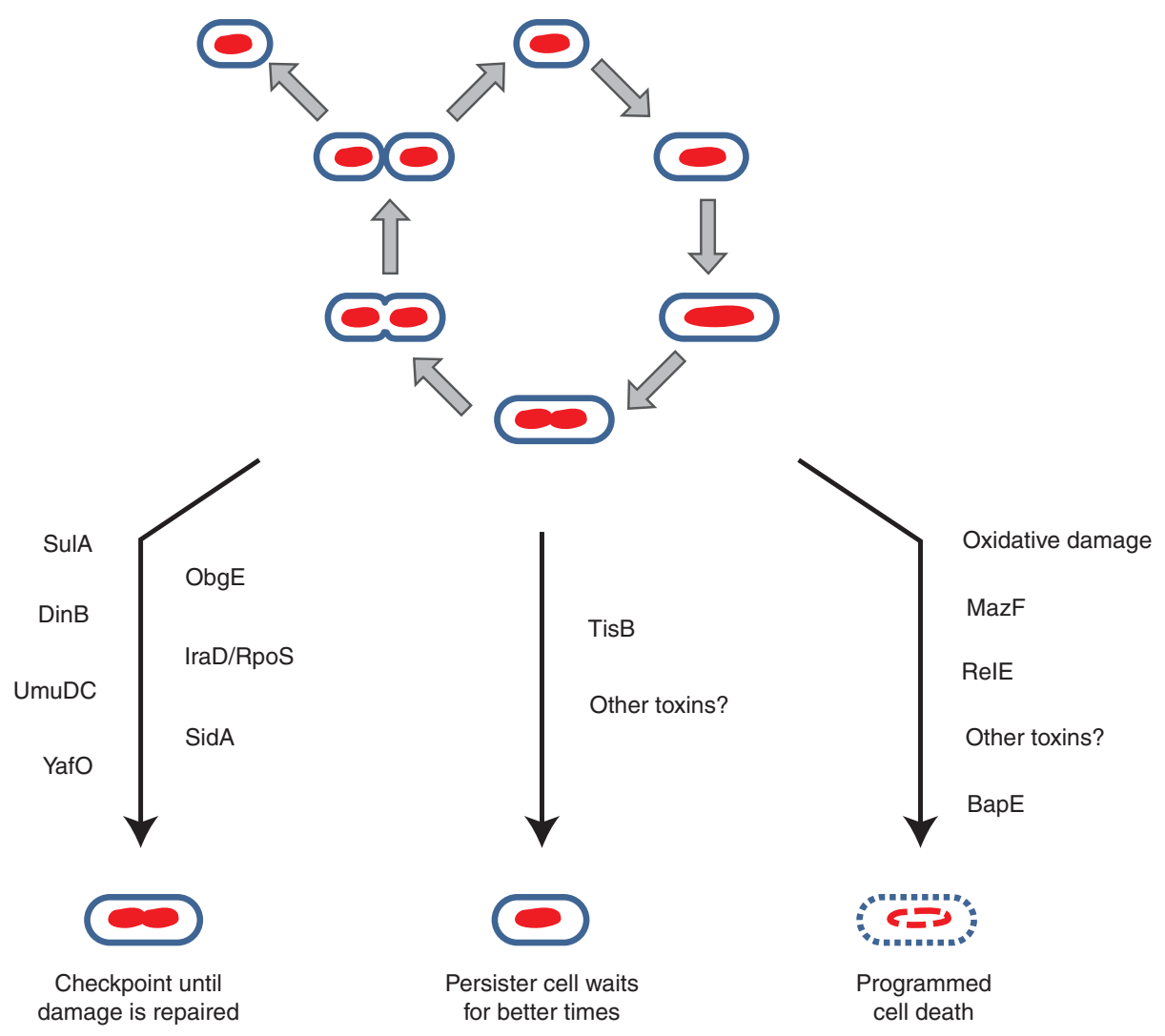

Figure 2. Factors implicated in DNA damage-inducible modulation of bacterial cell growth and death. Proteins and other factors that have been implicated in checkpoint induction, persister cell formation, and programmed cell death are depicted. Subsets of these proteins may act in distinct pathways; the diagram does not imply that all proteins next to an arrow act together. See text for details. 
K.N. Kreuzer

\section{Toxin-Antitoxin Pairs as Checkpoints}

One possible checkpoint mechanism involves the action of a toxin-antitoxin (TA) system (for reviews, see Gerdes et al. 2005; Magnuson 2007; Yamaguchi et al. 2011). Several toxin genes are induced during an SOS response, although the physiological impacts of most are yet to be deciphered (see Kawano et al. 2007; Magnuson 2007; Unoson and Wagner 2008; Yamaguchi et al. 2011; Gerdes and Maisonneuve 2012). An interesting example involves the $E$. coli yaf $N$ and $y a f O$ genes, which are downstream of $\operatorname{din} B$, and like $\operatorname{din} B$, up-regulated during an SOS response (Singletary et al. 2009). Although not proven, the investigators suggest that the toxin YafO delays reentry into the cell cycle following an SOS response, acting as a checkpoint to allow maximal repair of the damage. YafO was recently shown to be a ribosome-associated RNase that inhibits protein synthesis via mRNA cleavage (Zhang et al. 2009).

\section{TLS-Related Checkpoints}

E. coli TLS polymerases Pol IV (DinB) and Pol V $\left(\mathrm{UmuD}_{2}^{\prime} \mathrm{C}\right)$ have both been linked to a possible checkpoint-like function relating to the SOS response (also see review on TLS polymerases by Fuchs and Fujii 2013). As described in detail by Friedberg et al. (2006), the intact form of UmuD together with UmuC appears to function in a damage-inducible checkpoint. RecAdependent cleavage of UmuD late in the SOS response can generate the active Pol V $\left(\mathrm{UmuD}_{2-}^{\prime}\right.$ C), but this is apparently not the only function of this protein. Striking evidence for a possible checkpoint function is that expression of noncleavable UmuD (together with UmuC) increases survival after UV damage by delaying the resumption of DNA replication, which apparently allows more time for excision repair to fix UV-induced lesions (Opperman et al. 1999). Furthermore, separation-of-function mutations have been isolated to distinguish the checkpoint function and TLS polymerase activity (Sutton and Walker 2001).

Interestingly, some parallel evidence suggests that DinB, which encodes the TLS poly- merase Pol IV, might also be a checkpoint effector. Overexpression of DinB was shown to rapidly block replication fork movement, and mutations in DinB differentially affected this fork blockage activity and TLS activity (Uchida et al. 2008). The DinB protein was also shown to displace Pol III from active replisomes in vitro, providing a molecular explanation for the in vivo fork blockage (Furukohri et al. 2008; Uchida et al. 2008). Further research is clearly needed to elucidate the physiological significance of the apparent checkpoint activities of UmuDC and DinB, both of which are induced by SOS.

\section{Checkpoints Relating to Stringent Response}

Two other checkpoint-like responses have been linked to the stringent response and are related to DNA replication inhibition (for review of the stringent response, see Potrykus and Cashel 2008; Srivatsan and Wang 2008; Battesti et al. 2011; Dalebroux and Swanson 2012). First, mutations in the E. coli obgE gene were shown to cause a dramatic hypersensitivity to DNA replication inhibitors, leading to a model in which the ObgE GTPase acts as a replication checkpoint protein of some kind (Foti et al. 2005). Based on synergy with recombination proteins, the investigators proposed that $\mathrm{ObgE}$ action prevents the accumulation of regressed forks and DNA breaks during the inhibition of replication. Subsequently, ObgE was found to bind ppGpp at physiologically relevant concentrations in vitro, and inactivation of $\mathrm{ObgE}$ activity was shown to increase the pppGpp to ppGpp ratio in vivo during the stringent response (Persky et al. 2009).

In a second and perhaps related case involving $B$. subtilis, induction of the stringent response to starvation was shown to rapidly inhibit DNA replication (Wang et al. 2007). Strikingly, the in vivo replication block was traced to a direct inhibitory effect of (p)ppGpp on DNA primase activity. The arrested replication forks did not recruit RecA protein, indicating that the mechanism of fork stalling was benign and presumably protective against genotoxic or potentially lethal fork processing events (Wang 
et al. 2007). E. coli primase is also inhibited by (p)ppGpp, and the investigators speculated that the above ObgE effects might be exerted through primase inhibition (Macięg et al. 2010; also see Kanjee et al. 2012).

Another interesting connection to the stringent response involves the protein IraD, an antiadaptor that inhibits the proteolysis of the stress-response sigma factor RpoS. E. coli iraD or rpoS knockout mutants are hypersensitive to azidothymidine, hydrogen peroxide and phleomycin, agents that cause DNA damage or inhibit DNA replication (Merrikh et al. 2009). IraD is induced after DNA damage in a LexA-independent fashion, and its induction stabilizes RpoS against degradation (Zheng et al. 2001; Merrikh et al. 2009). These and other results argue that the RpoS-based stress response, via IraD induction, acts synergistically with the SOS response in survival after DNA damage or replication inhibition (Merrikh et al. 2009). The proteins induced during the stress response that promote survival remain to be determined.

\section{SOS Induction of Persister Cells} that Survive Drug Treatment

Although inhibition of cell division may in certain cases serve a checkpoint response, giving cells more time to repair damage, it can also (or instead) have a dramatic population effect of inducing so-called persister cells (for recent reviews, see Lewis 2010; Gerdes and Maisonneuve 2012). Persisters are dormant variants of normal cells that are highly tolerant to antibiotics, but usually formed in only tiny fractions of a cell population. Certain TA pairs are crucial in the formation of persister cells that resist antibiotic treatment, and one in particular plays a specific and dramatic role during the SOS response (Magnuson 2007; Tsilibaris et al. 2007; Dörr et al. 2010; Lewis 2010; Yamaguchi et al. 2011).

Dörr et al. (2009) found that SOS induction increases the fraction of persisters able to survive antibiotic treatment. Thus, preexposure to a low level of ciprofloxacin was found to increase survival to higher levels of the drug. Deletions of the SOS-inducible tisAB TA pair dra- matically reduced the fraction of persister cells, whereas deletion of other LexA-box-containing TA gene pairs had no effect (Dörr et al. 2010; Lewis 2010). Importantly, the adaptive response of pretreatment with a low level of drug was also abolished in the $t i s A B$ knockout (Dörr et al. 2010). Thus, SOS induction significantly increases persister cell formation by a TisB-dependent mechanism that turns out to involve membrane binding and disruption of the proton motive force (Unoson and Wagner 2008; Lewis 2010).

\section{Bacterial Programmed Cell Death (PCD)}

A number of recent studies suggest that bacteria undergo PCD under particularly stressful conditions, including treatment with agents that damage DNA and/or inhibit replication. At least one of these pathways bears striking resemblance to eukaryotic apoptosis. As will be described, however, contrary evidence also exists concerning some of these proposed pathways and more experiments are needed to clarify the extent and impact of bacterial PCD pathways.

\section{MazF and PCD}

The earliest studies that hinted at bacterial PCD involved the addiction modules that consist of TA pairs encoded by plasmids (for reviews, see Gerdes et al. 1990; Jensen and Gerdes 1995; Engelberg-Kulka and Glaser 1999; Gerdes et al. 2005). In this case, whenever a daughter cell arises without a copy of the plasmid because of a defective segregation event, the antitoxin decays faster than the toxin and the dominant toxin kills the cell (or at least arrests its growth). This is a sensible mechanism for plasmids to enforce addiction on their host, but then it is surprising that so many TA systems were found in chromosomal locations (see Magnuson 2007, for excellent discussion of possible TA functions).

One such chromosomal system that is widely conserved and extensively studied is the MazEF pair. Reports from one group argued that MazF toxin induction triggers a PCD path- 
way (Sat et al. 2001; Hazan et al. 2004), however, others instead detected reversible cell growth inhibition (Pedersen et al. 2002; Christensen et al. 2003; Tsilibaris et al. 2007). Godoy et al. (2006) also found evidence that MazF plays a role in killing after hydroxyurea treatment of E. coli, and argued that both views might be correct. Their argument is that MazF induction leads to growth inhibition that is usually reversible, but that certain extreme conditions (such as hydroxyurea treatment) put cells in a position from which they cannot recover from the induced growth stasis.

A very recent study presented evidence that a MazF-dependent PCD pathway interacts with an apoptotic-like death pathway that is SOS dependent (Erental et al. 2012). Support for a general role of MazF in PCD comes the demonstration that MazF is essential for a PCD pathway in Myxococcus xanthus development ( $\mathrm{Na}-$ riya and Inouye 2008). There is clearly much to be learned about the precise role of MazF and other chromosomally encoded toxins under various stressful conditions.

\section{Hydroxyl Radical Generation and PCD}

In 2007, Kohanski et al. (2007) reported that bacteriocidal antibiotics, including ones that do not induce DNA damage (e.g., aminoglycosides), induce the production of deleterious hydroxyl radicals. Multiple experiments indicated that radical production contributes to cell death after antibiotic treatment. The proposed PCD pathway involves the tricarboxylic acid cycle, transient depletion of nicotinamide adenine dinucleotide, destabilization of iron-sulfur clusters, and stimulation of the Fenton reaction. A later study provided evidence that a major cause of the PCD is induced oxidation of guanine to 8-oxo-guanine in the nucleotide pools, which, on incorporation into nucleic acids, was proposed to provoke double-strand breaks in DNA and mistranslation of mRNA (Foti et al. 2012).

Dwyer et al. (2012) reported that this proposed PCD pathway is closely related to eukaryotic apoptosis. They found hallmarks of eukaryotic-like apoptosis in E. coli, including phosphatidyl serine exposure on the cell surface, chromosome condensation, and DNA fragmentation. In addition, they found that RecA binds to peptides that also serve as substrates for eukaryotic caspases, and that degradation is regulated by ClpXP protease under conditions of cell killing (Dwyer et al. 2012). An initial result of the induction of oxidative damage is RecA-dependent induction of SOS, and so the SOS response appears caught in the middle of the PCD pathway.

Two recent studies, however, have cast doubt on the role of hydroxyl radical production in PCD by failing to confirm important predictions of the model. Neither hydrogen peroxide nor intracellular-free iron were induced after antibiotic treatment as would be expected, and lethality persisted in the absence of oxygen (Keren et al. 2013; Liu and Imlay 2013).

\section{PCD in Caulobacter}

As mentioned above, $C$. crescentus induces an SOS response that includes a cell-cycle checkpoint. At higher levels of DNA damage and/or in the absence of a functional SOS response, this species also induces a PCD pathway that resembles eukaryotic apoptosis (Bos et al. 2012). Cell death is associated with positive staining by two apoptosis-indicative dyes, one that is dependent on membrane depolarization and the other on chromosome fragmentation. In this case, chromosome cleavage was shown to be dependent on an endonuclease christened BapE for bacterial apoptosis endonuclease, which is both necessary and sufficient for the induced cell death (Bos et al. 2012).

\section{SOS-INDEPENDENT DNA DAMAGE RESPONSES}

The SOS pathway is augmented by newly discovered DNA damage response pathways in some bacterial species, and in others, all DNA damage response appears independent of SOS. In E. coli, the adaptive response to DNA alkylation (see below) has been well studied for decades, and transcriptome analyses uncovered additional LexA-independent but damage-in- 
DNA Damage Responses in Prokaryotes

ducible networks of genes that remain to be studied (Courcelle et al. 2001; Zheng et al. 2001; Khil and Camerini-Otero 2002; Friedberg et al. 2006). This section highlights a few novel pathways that augment or replace SOS in response to DNA damage.

\section{The Adaptive Response: AidB and DNA} Protection in Starved Cells

As reviewed by Friedberg et al. (2006), the adaptive response involves the transcriptional induction of several genes in response to alkylation damage to the DNA. Alkyltransferase protein Ada, on transfer of a methyl group from DNA to the Cys38 residue, becomes a transcriptional activator for genes including ada, alkA, alkB, and $\operatorname{aidB}$ (Fig. 3A). In addition to its role in regulation, the Ada protein facilitates DNA re- pair directly via alkyltransferase activity. AlkA, on the other hand, is a DNA glycosylase that initiates base excision repair of alkylated bases. Recent results have advanced our understanding of the function of the AidB protein.

Almost 20 years ago, AidB was noted to be homologous to acyl-coenzyme A (acyl-CoA) dehydrogenases, and cells overexpressing the protein had both increased isovaleryl-CoA dehydrogenase activity and reduced mutagenesis after treatment with an alkylating agent (Landini et al. 1994). Notably, based on their results, these investigators proposed that AidB might serve a detoxification role. Subsequent biochemical and structural studies supported the assignment of AidB as an acyl-CoA dehydrogenase, and also showed that AidB contains a small carboxy-terminal DNA-binding domain (Rohankhedkar et al. 2006; Bowles et al. 2008).

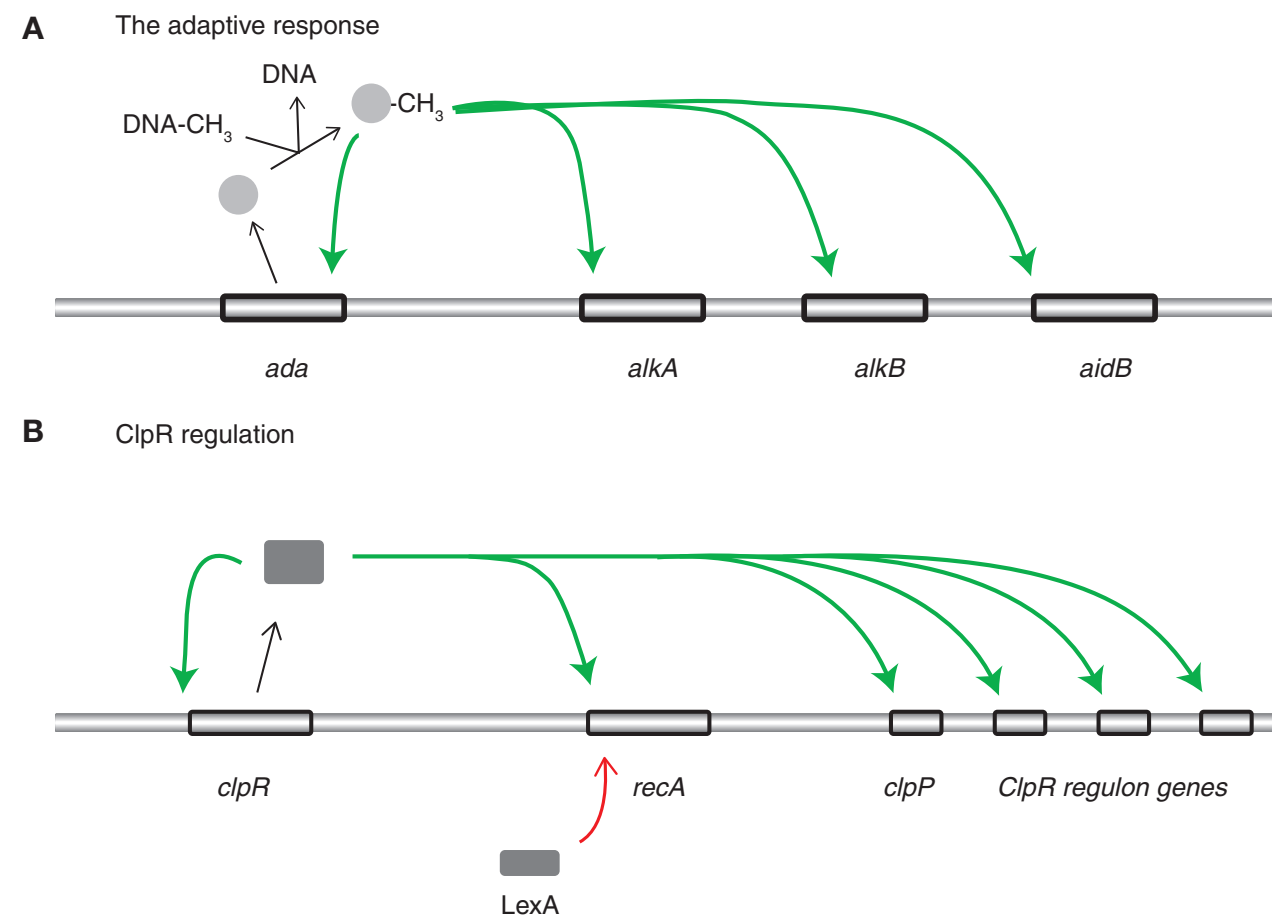

Figure 3. SOS-independent DNA damage responses. (A) In the adaptive response, transfer of an alkyl group from DNA to the Cys-38 residue of the Ada protein generates the activator for the adaptive response, which promotes transcription of the ada gene along with alkA, alkB, and aidB genes. (B) Most damage-inducible genes in mycobacteria are regulated by ClpR, a transcriptional activator that binds to the promoter region of its own gene as well as that of the recA, clpP, and other regulon genes. The recA gene is also controlled by LexA and the SOS response from the second of two recA promoters. 
K.N. Kreuzer

The functional relevance of the DNA-binding domain is quite remarkable. AidB was characterized as a locus-specific detoxification protein (Rippa et al. 2011; also see Rippa et al. 2010). AidB protein binds, via the carboxy-terminal domain, to UP elements located at strong promoters, promoting efficient transcription of various genes including DNA repair and housekeeping genes. Strikingly, AidB was found to protect such downstream genes from alkylation damage. The investigators suggested that the protein, via its dehydrogenase active site, inactivates alkylating agents as they approach DNA. When the DNA-binding domain was ablated to result in free-floating AidB, it provided a general protective effect. The protective action of AidB is reminiscent of the bacterial Dps proteins (Zhao et al. 2002; Friedberg et al. 2006). Dps is present at high levels in stationary phase cells and is also induced in response to oxidative damage by the OxyR regulatory system (Altuvia et al. 1994). Like Dps, AidB is also induced in stationary phase in a $\sigma^{\mathrm{S}}$-dependent fashion (Volkert et al. 1994; Lacour et al. 2002), and therefore these two proteins collaborate to protect DNA from oxidative assault during starvation.

\section{ClpR Regulation in Mycobacteria}

Although mycobacteria have an SOS system, most damage-inducible genes are instead controlled by a regulator in the ClpR family (Rv2745c in M. tuberculosis and Ms2694 in Mycobacterium smegmatis; Rand et al. 2003; Gamulin et al. 2004; Wang et al. 2011). The ClpR regulator binds to the promoter regions of many damage-inducible genes, including DNA repair genes, recognizing an altered promoter structure in which -10 and -35 consensus elements are separated by an unusually short 8 bp (Fig. 3B) (Wang et al. 2011). Interestingly, the recA gene itself is up-regulated from two different promoters, one in a LexA (SOS)-dependent fashion and one in a ClpR-dependent fashion. In M. tuberculosis, the ClpR response is induced by a broad array of stresses, including diamide, heat, SDS, hypoxia, infecting macrophages, vancomycin, low pH, and DNA damage (see Wang et al. 2011 for citations). The ClpR family of regulators was first uncovered as transcriptional activators of Clp protease (Bellier and Mazodier 2004; Engels et al. 2004; Ventura et al. 2005). Thus, the response is more accurately classified as a broad stress response with an important component related to DNA damage and its repair. All mycobacteria and some other actinomycetes carry conserved homologs of Rv2745c, suggesting that the ClpR response pathway is broadly spread in this group of bacteria.

Damage Response in the Highly Radioresistant Deinococcus radiodurans

D. radiodurans has the remarkable ability to reconstitute its genome after very high levels of double-strand breaks and other forms of DNA damage induced by ionizing radiation (IR) or desiccation, which is likely the natural stress that led to the evolution of its radioresistance (for reviews, see Mattimore and Battista 1996; Battista 1997; Cox et al. 2010; Slade and Radman 2011). The high level of resistance depends on both efficient DNA repair pathways and an unusually robust antioxidation system that protects proteins, including critical repair proteins, from oxidative damage and inactivation (Daly et al. 2007, 2010; Daly 2009; see "Reconstitution of Heavily Damaged Chromosomes" below for discussion of DNA repair mechanisms). As expected, resistance to IR also depends on robust regulation of repair and protective proteins. Using microarray expression approaches, Tanaka et al. (2004) identified > 70 IR-induced genes in this organism, including both DNA repair proteins (e.g., RecA) and proteins involved in alleviating oxidative stress.

The recA gene of $D$. radiodurans is induced after DNA damage, but surprisingly, neither of the two LexA homologs of the organism is required for activation although they are cleaved in a RecA-dependent manner (Narumi et al. 2001; Bonacossa de Almeida et al. 2002; Earl et al. 2002; Hua et al. 2003; Satoh et al. 2006; Slade and Radman 2011). The recA gene and at least 28 additional genes, many encoding DNA repair proteins, contain a conserved motif called the radiation/desiccation response motif 
(Makarova et al. 2007). Recently, a key regulatory protein, PprI (also called IrrE and DR0167), was shown to bind the $r e c A$ (and $\operatorname{pprA}$ ) gene promoters in vitro, and interestingly, was found at the IR-inducible promoters in vivo only after DNA damage (measured by ChIP; Lu et al. 2012). PprI itself is constitutively expressed, suggesting that DNA damage leads to posttranslation activation of PprI by some mechanism, but the details are currently unknown.

In addition to the key role of PprI, several protein kinases and related proteins have been implicated in the response to DNA damage in D. radiodurans: DrRRA (DR2418), an apparent response regulator of a two-component-like system (Wang et al. 2008); DR2518, a predicted transmembrane protein of the serine-threonine kinase family (Rajpurohit and Misra 2010); and RadRS (DRB0091/DRB0090), a two-component system that includes the RadS histidine kinase, which can phosphorylate both itself and its partner RadR, a DNA binding protein with currently unknown targets (Desai et al. 2011). Further investigations are needed to understand the precise and apparently overlapping roles of PprI, DrRRA, DR2518, and the RadRS proteins in the DNA damage response in $D$. radiodurans, and to explore whether damage-inducible protein kinases are used broadly in bacteria.

\section{DNA Damage Induction of Competence} Proteins

In some species, DNA damage induces competence proteins rather than proteins involved in DNA repair (for review, see Charpentier et al. 2012). Such is the case for both Streptococcus species and Helicobacter pylori, both of which lack any obvious LexA homolog (Prudhomme et al. 2006; Dorer et al. 2010, 2011). Despite the lack of LexA in H. pylori, RecA is still required for induction of competence (and other) proteins (Dorer et al. 2010). Amazingly, competence itself is also required for the up-regulation seen after DNA damage, leading to a positive feedback loop (Dorer et al. 2011). The mechanism of this remarkable regulatory loop is unclear, but it has been suggested that either up- take of exogenous DNA is needed for the inducing RecA-DNA complexes, or that RecA associates with the competence machinery to mediate transcriptional signaling (Dorer et al. 2011). The significance of the connection between competence and DNA damage demands further study; presumably, transformation speeds the generation of novel variants during stressful conditions and perhaps imported exogenous DNA provides a template for chromosomal recombinational repair (Dorer et al. 2011).

\section{PROKARYOTIC STRATEGIES FOR REPLICATING DAMAGED DNA}

Bacterial replication machineries and the proteins that underpin replication (mostly recombination proteins) allow dramatic and powerful strategies for completing the replication of damaged DNA. There is now evidence that replication forks can jump forward (reprime the leading strand), back up (regress), and repair after getting broken, perhaps even undergoing intentional breakage followed by repair. In addition, traditional repair can be coupled to the process of replication, either when fork regression regenerates a repair template in the parental DNA (see below) or by means of a coupled recombination-excision repair event after the fork passes (Bichari et al. 2009). A major challenge for the field is to decipher the interplay between these various pathways and how the appropriate pathway is chosen for a particular form of DNA damage.

An overview of some of these topics with recent advances will be presented here, and the reader is referred to comprehensive reviews of various aspects that have appeared in recent years (Cox et al. 2000; Michel 2000; Cox 2001; Lusetti and Cox 2002; McGlynn and Lloyd 2002; Courcelle and Hanawalt 2003; Kreuzer 2005; Friedberg et al. 2006; Heller and Marians, 2006b; Michel et al. 2007; Atkinson and McGlynn 2009; Gabbai and Marians 2010). The reader may also be interested in the related topic of replication-transcription collisions discussed in recent reviews (Pomerantz and O'Donnell 2010; McGlynn et al. 2012). 
K.N. Kreuzer

Repriming of the Leading Strand Ahead of the Fork

In contrast to simple textbook models in which the leading strand of a bacterial replication fork is synthesized continuously whereas the lagging strand is discontinuous, analyses of in vivo replication have suggested discontinuities in both newly synthesized strands, particularly after DNA damage ( for discussion of early studies, see Friedberg et al. 2006; also see Amado and Kuzminov 2006). How could leadingstrand replication reinitiate after a blocking lesion stalls the leading-strand DNA polymerase (Fig. 4A)? One model invokes the use of RNA polymerase transcripts hybridizing to the parental leading-strand template downstream of the blocking lesion (Camps and Loeb 2005; Friedberg et al. 2006). Recent biochemical studies have uncovered a second attractive model. Heller and Marians (2006a) showed that under appropriate conditions, the DnaG helicase of the E. coli replisome can synthesize primers to allow reinitiation of leading-strand synthesis downstream of a block. In a later study, this pathway was shown to operate without any dissociation and reloading of the replication machinery, demonstrating an inherent tolerance of the replisome to blocking lesions (Yeeles and Marians 2011).

\section{Replication Fork Breakage and Restart}

As discussed in detail by Friedberg et al. (2006), homologous recombination provides an excellent pathway to restart broken replication forks (also see Kuzminov 1999; Cox et al. 2000; Kreuzer 2005; Michel et al. 2007). Replication forks can become broken by encounters with template nicks (Kuzminov 2001) and from fork cleavage reactions such as those mentioned in "Fork Regression and Template Switching" below. The basic pathway for reconstituting broken replication forks involves a one-ended strand invasion reaction in which the broken end invades the intact homologous duplex from which it had broken away (Fig. 4B). After D-loop formation, the invading $3^{\prime}$ end is used as a primer for synthesis of a new leading strand and the displaced single-stranded region is a loading site for a helicase-primase complex, allowing lagging-strand synthesis (Fig. 4B). This pathway has been reconstituted in vitro, and depends critically on the PriA protein for the loading of replicative helicase $\mathrm{DnaB}$ onto the D-loop intermediate (Liu and Marians 1999; Liu et al. 1999; Xu and Marians 2003).

\section{Fork Regression and Template Switching}

Because the two daughter strands have complementary sequence, they are able to form a duplex with each other if unwound from parental template DNA in a reaction called replication fork regression (Fig. 5). The possibility that regression could serve as a damage bypass mechanism was recognized decades ago (Fujiwara and Tatsumi 1976; Higgins et al. 1976).

Replication fork regression can be considered as either productive or pathological, and it seems likely that this balance is determined by the nature of the blocking agent and the available repair/recombination proteins (Atkinson and McGlynn 2009). The potentially productive reactions that can be promoted by regression include clearing the parental template DNA for a repair reaction, allowing template switching that can bypass a template lesion, and reinvasion of the extruded arm into the template duplex ahead of the (regressed) fork (Fig. 5A, $B$, and $C$, respectively). An excellent and comprehensive review on fork regression was published recently (Atkinson and McGlynn 2009), and only a brief overview will be presented here.

Evidence that stalled or blocked E. coli chromosomal replication forks that undergo regression first arose when Michel and colleagues found double-strand chromosomal breaks when the cells carried debilitating mutations in certain replication proteins (Michel et al. 1997). Detection of the breaks required inactivation of RecBCD, presumably due to a major role of RecBCD in processing the extruded arm at the regressed fork. The subsequent finding that RuvABC is required for break formation argued that fork regression, which creates a Holliday junction at the fork, was involved in the chromosomal breakage pathway (Seigneur et al. 
DNA Damage Responses in Prokaryotes

\section{A Reprime leading strand}

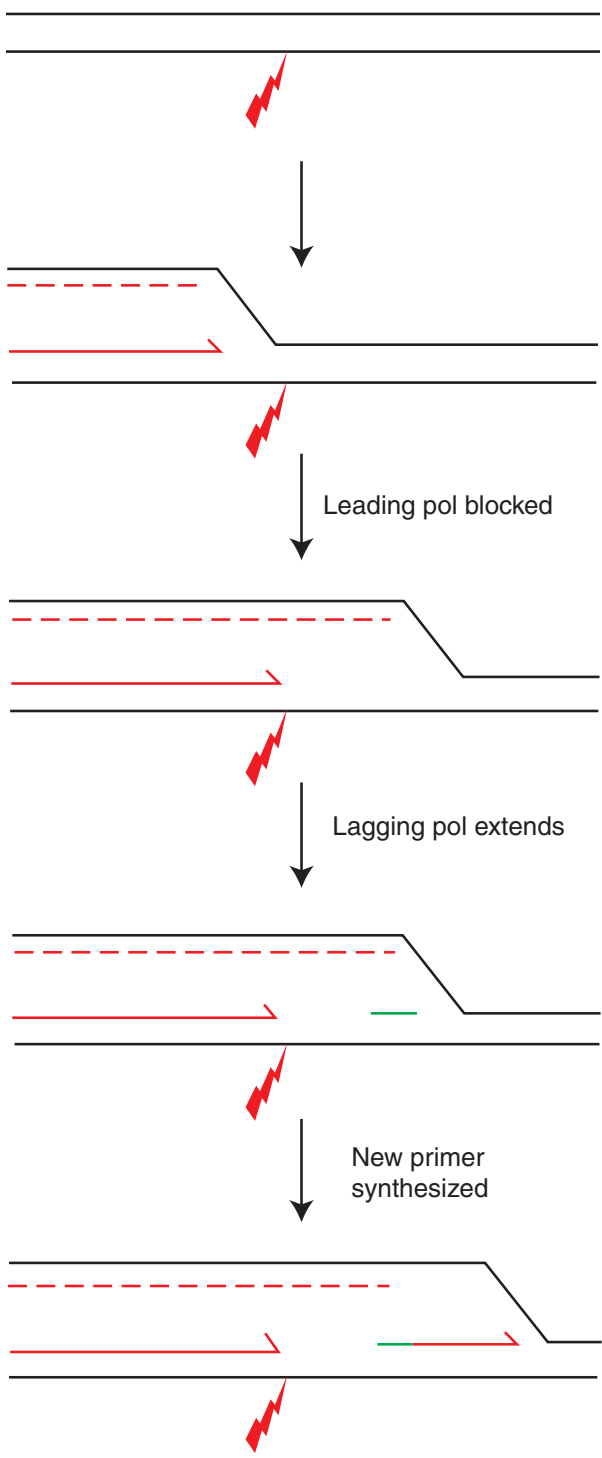

B Broken fork restart

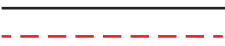

$-------$

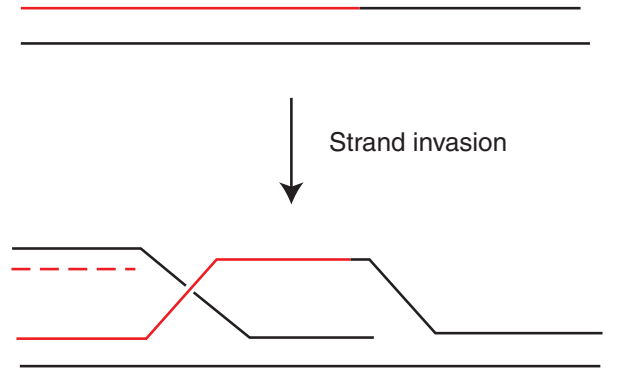

Reinitiate replication

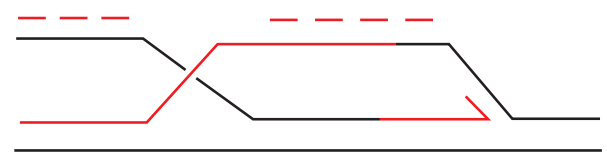

Branch migration

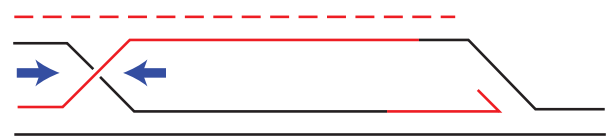

Resolve junction

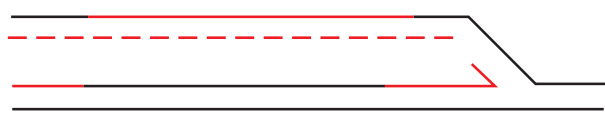

Figure 4. Models of fork rescue via repriming of the leading strand and a recombinational repair reaction. (A) A blocking lesion on the leading-strand template can be overcome by a new priming event downstream of the blocking lesion. As described in the text, a nascent RNA synthesized by RNA polymerase could provide a primer (green), as could the DnaG primase in the replisome. All newly synthesized DNA is in red, and the blocking lesion is indicated by the small lightning bolt. $(B)$ A broken replication fork can be reconstituted by homologous recombination. In this model, the broken end undergoes strand invasion to create a D-loop structure, which serves as assembly site for a new rightward facing replisome. Branch migration and Holliday junction resolution can remove the branched connection between the two daughter molecules. All newly synthesized DNA is in red, and the blue arrows indicate one of several possible junction resolution reactions (cleavage of the cross strands followed by religation). pol, Polymerase. 
K.N. Kreuzer

A

Regression allows repair
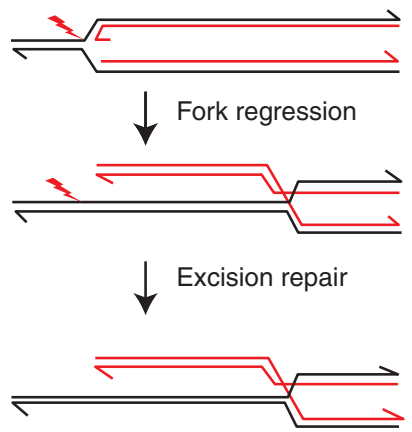

Reverse regression
B
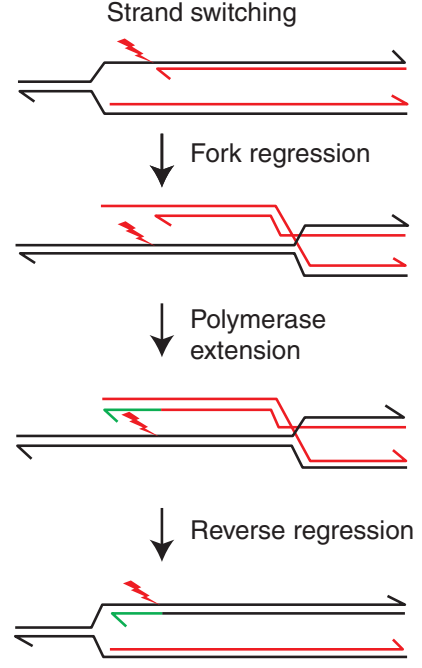

C
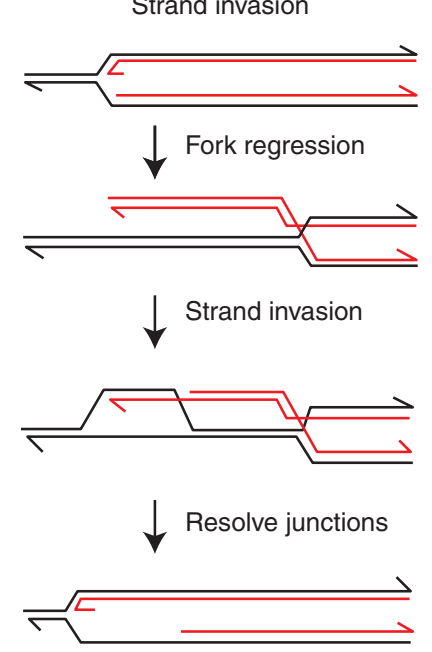

Figure 5. Models of fork rescue via fork regression. $(A)$ When the replication fork encounters a template lesion (small lightning bolt), fork regression can return the lesion into an environment of simple duplex DNA to facilitate a traditional repair event such as excision repair. $(B)$ In cases in which lagging-strand synthesis extends beyond the site of a lesion on the leading-strand template, fork regression provides an opportunity for a strand switching event in which polymerase extension on the extruded arm (DNA in green) effectively bypasses the lesion so that replication can be completed. This gives the cell another cell division cycle to repair the damage using conventional repair pathways. Fork regression can be resolved either by reversal of fork regression $(A, B)$, nucleolytic digestion of the extruded arm (not shown), or $(C)$ strand invasion of the extruded arm ahead of the replication fork. In this figure, all newly synthesized DNA is in red (except for the green template switch patch).

1998). Physical evidence consistent with replication fork regression in E. coli was later obtained using neutral-neutral two-dimensional agarose gel electrophoresis of replicating damaged plasmids (Courcelle et al. 2003), although the detected intermediates might possibly have been some other branched form that migrated in a similar region of the gel. An analysis in phage T4-infected E. coli provided more definitive physical evidence of in vivo fork regression by characterizing site-specific regressed forks (Long and Kreuzer 2008, 2009). Replication fork regression can be driven, at least in vitro, by positive supercoiling of the template ahead of the fork, any of a number of helicases that act on branched DNA, and by strand exchange proteins (for review, see Atkinson and McGlynn 2009).

Khan and Kuzminov (2012) carefully analyzed replication and repair after UV treatment in E. coli. They reached the surprising conclu- sion that fork regression, followed by induced breakage of the regressed fork, was necessary for survival under certain conditions of DNA damage. The breaks were not detected in wild-type cells because of efficient break repair involving RecA and RecBCD. Evidence that the induced breakage pathway is important for survival comes from the requirement for both RecA and RuvABC for optimal survival under these conditions (Khan and Kuzminov 2012). The investigators argue that this pathway becomes critical when DNA damage is closely spaced on the two template strands, but not so closely spaced that regression is impossible. Induced cleavage in this situation is proposed to give the parental template more time to repair via the nucleotide excision repair pathway before the recombination events that restart the broken forks (Khan and Kuzminov 2012). Further experiments are needed to understand the balance between this pathway of induced breakage and 
the arguably simpler pathway of temporary regression to expose template damage to the repair machinery (as in Fig. 5A).

\section{Reconstitution of Heavily Damaged Chromosomes}

As mentioned above in "ClpR Regulation in Mycobacteria," D. radiodurans has the remarkable ability to reconstitute its genome after very high levels of double-strand breaks and other forms of DNA damage (for review, see Battista 1997; Cox et al. 2010; Slade and Radman 2011). This genome reconstitution was shown to involve two major phases, the first relying on a special form of DNA replication (Zahradka et al. 2006). The so-called extended synthesisdependent strand-annealing pathway in the first phase begins with extensive exonucleolytic digestion to generate invasive $3^{\prime}$ ends. The heart of this first phase is then a replication pathway that extends the $3^{\prime}$ ends of the numerous DNA fragments, using unbroken regions of homologous template strands. As in transcription, the newly synthesized strands are somehow dissociated from the template. This generates many $3^{\prime}$ extensions, and in the second stage, annealing of complementary extensions begins to piece together longer stretches of the genome in a RecAdependent process, culminating in completion of an intact duplex genome (Zahradka et al. 2006). More recent studies have elucidated detailed protein requirements and mechanistic steps in the genome reconstitution pathway (Slade et al. 2009; Bentchikou et al. 2010). Remarkably, selection for radioresistant E. coli successfully generated strains that are nearly as resistant as $D$. radiodurans, revealing that a relatively small number of mutational changes can allow E. coli to follow a similar (or at least an effective) pathway of genome reconstitution (Harris et al. 2009).

\section{CLOSING REMARKS}

The field of DNA damage responses in bacteria continues to provide extremely interesting biology and mechanism. Transcriptional responses including SOS regulate not only DNA repair enzymes, but also very diverse proteins involved in cell division, genetic rearrangements and exchange, mutation, and virulence factor production. Furthermore, DNA damage responses are variable between bacterial species, apparently being adapted for particular needs and ecological lifestyles. Survival after DNA damage is influenced by dynamic regulatory mechanisms as well as cell growth inhibition, death pathways, and impressive replication fork gymnastics in response to template lesions. Future studies should provide a much better understanding of how these multiple layers complement each other for optimal survival.

\section{ACKNOWLEDGMENTS}

K.N.K. thanks David T. Long for an early draft of the Figure 5 diagram and an anonymous reviewer for helpful comments on the content and organization of this article. Research in the author's laboratory is supported by grants GM066934 and GM072089 from the National Institutes of Health.

\section{REFERENCES}

${ }^{*}$ Reference is also in this collection

Adikesavan AK, Katsonis P, Marciano DC, Lua R, Herman C, Lichtarge O. 2011. Separation of recombination and SOS response in Escherichia coli RecA suggests LexA interaction sites. PLoS Genet 7: e1002244.

Aertsen A, Michiels CW. 2006. Upstream of the SOS response: Figure out the trigger. Trends Microbiol 14: $421-423$.

Altuvia S, Almirón M, Huisman G, Kolter R, Storz G. 1994. The dps promoter is activated by OxyR during growth and by IHF and $\sigma \mathrm{S}$ in stationary phase. Mol Microbiol 13: 265-272.

Amado L, Kuzminov A. 2006. The replication intermediates in Escherichia coli are not the product of DNA processing or uracil excision. J Biol Chem 281: 22635-22646.

Atkinson J, McGlynn P. 2009. Replication fork reversal and the maintenance of genome stability. Nucleic Acids Res 37: 3475-3492.

Au N, Kuester-Schoeck E, Mandava V, Bothwell LE, Canny SP, Chachu K, Colavito SA, Fuller SN, Groban ES, Hensley LA. 2005. Genetic composition of the Bacillus subtilis SOS system. J Bacteriol 187: 7655-7666.

Auchtung JM, Lee CA, Monson RE, Lehman AP, Grossman AD. 2005. Regulation of a Bacillus subtilis mobile genetic element by intercellular signaling and the global DNA damage response. Proc Natl Acad Sci 102: 12554-12559. 
K.N. Kreuzer

Ayora S, Carrasco B, Cárdenas PP, César CE, Cañas C, Yadav T, Marchisone C, Alonso JC. 2011. Double-strand break repair in bacteria: A view from Bacillus subtilis. FEMS Microbiol Rev 35: 1055-1081.

Bagdasarian M, Bailone A, Angulo JF, Scholz P, Devoret R. 1992. PsiB, an anti-SOS protein, is transiently expressed by the $\mathrm{F}$ sex factor during its transmission to an Escherichia coli K-12 recipient. Mol Microbiol 6: 885-893.

Baharoglu Z, Mazel D. 2011. Vibrio cholerae triggers SOS and mutagenesis in response to a wide range of antibiotics: A route towards multiresistance. Antimicrob Agents Chemother 55: 2438-2441.

Baharoglu Z, Bikard D, Mazel D. 2010. Conjugative DNA transfer induces the bacterial SOS response and promotes antibiotic resistance development through integron activation. PLoS Genet 6: e1001165.

Baharoglu Z, Krin E, Mazel D. 2012. Connecting environment and genome plasticity in the characterization of transformation-induced SOS regulation and carbon catabolite control of the Vibrio cholerae integron integrase. J Bacteriol 194: 1659-1667.

Bailone A, Bäckman A, Sommer S, Célérier J, Bagdasarian MM, Bagdasarian M, Devoret R. 1988. PsiB polypeptide prevents activation of RecA protein in Escherichia coli. Molec Gen Genet 214: 389-395.

Battesti A, Majdalani N, Gottesman S. 2011. The RpoS-mediated general stress response in Escherichia coli. Annu Rev Microbiol 65: 189-213.

Battista JR. 1997. Against all odds: The survival strategies of Deinococcus radiodurans. Annu Rev Microbiol 51: $203-$ 224.

Beaber JW, Hochhut B, Waldor MK. 2004. SOS response promotes horizontal dissemination of antibiotic resistance genes. Nature 427: 72-74.

Bellanger X, Morel C, Decaris B, Guédon G. 2007. Derepression of excision of integrative and potentially conjugative elements from Streptococcus thermophilus by DNA damage response: Implication of a cI-related repressor. J Bacteriol 189: 1478-1481.

Bellanger X, Morel C, Decaris B, Guédon G. 2008. Regulation of excision of integrative and potentially conjugative elements from Streptococcus thermophilus: Role of the arp1 repressor. J Mol Microbiol Biotech 14: 16-21.

Bellier A, Mazodier P. 2004. ClgR, a novel regulator of $c l p$ and lon expression in Streptomyces. J Bacteriol 186: 3238-3248.

Bentchikou E, Servant P, Coste G, Sommer S. 2010. A major role of the RecFOR pathway in DNA double-strand-break repair through ESDSA in Deinococcus radiodurans. PLoS Genet 6: e1000774.

Bichari M, Fuchs RPP, Cordonnier A, Lambert IB. 2009. Preferential post-replication repair of DNA lesions situated on the leading strand of plasmids in Escherichia coli. Mol Microbiol 71: 305-314.

Black CG, Fyfe JA, Davies JK. 1998. Absence of an SOS-like system in Neisseria gonorrhoeae. Gene 208: 61-66.

Bonacossa de Almeida C, Coste G, Sommer S, Bailone A. 2002. Quantification of RecA protein in Deinococcus radiodurans reveals involvement of RecA, but not LexA, in its regulation. Mol Genet Genomics 268: 28-41.
Bos J, Yakhnina AA, Gitai Z. 2012. BapE DNA endonuclease induces an apoptotic-like response to DNA damage in Caulobacter. Proc Natl Acad Sci 109: 8096-18101.

Bowles T, Metz AH, O'Quin J, Wawrzak Z, Eichman BF. 2008. Structure and DNA binding of alkylation response protein AidB. Proc Natl Acad Sci 105: 5299-15304.

Butala M, Zgur-Bertok D, Busby SJ. 2009. The bacterial LexA transcriptional repressor. Cell Mol Life Sci 66: 9293.

Butala M, Klose D, Hodnik V, Rems A, Podlesek Z, Klare JP, Anderluh G, Busby SJ, Steinhoff HJ, Zgur-Bertok D. 2011. Interconversion between bound and free conformations of LexA orchestrates the bacterial SOS response. Nucleic Acids Res 39: 6546-6557.

Camps M, Loeb LA. 2005. Critical role of R-loops in processing replication blocks. Front Biosci 10: 689-698.

Centore RC, Lestini R, Sandler SJ. 2008. XthA (Exonuclease III) regulates loading of RecA onto DNA substrates in log phase Escherichia coli cells. Mol Microbiol 67: 88-101.

Charpentier X, Polard P, Claverys JP. 2012. Induction of competence for genetic transformation by antibiotics: Convergent evolution of stress responses in distant bacterial species lacking SOS? Curr Opin Microbiol 15: 570576.

Christensen SK, Pedersen K, Hansen FG, Gerdes K. 2003. Toxin-antitoxin loci as stress-response-elements: ChpAK/MazF and ChpBK cleave translated RNAs and are counteracted by tmRNA. J Mol Biol 332: 809-819.

Cirz RT, O’Neill BM, Hammond JA, Head SR, Romesberg FE. 2006. Defining the Pseudomonas aeruginosa SOS response and its role in the global response to the antibiotic ciprofloxacin. J Bacteriol 188: 7101-7110.

Cirz RT, Jones MB, Gingles NA, Minogue TD, Jarrahi B, Peterson SN, Romesberg FE. 2007. Complete and SOSmediated response of Staphylococcus aureus to the antibiotic ciprofloxacin. J Bacteriol 189: 531-539.

Courcelle J, Hanawalt PC. 2003. RecA-dependent recovery of arrested DNA replication forks. Annu Rev Genet 37: 611-646.

Courcelle J, Khodursky A, Peter B, Brown PO, Hanawalt PC. 2001. Comparative gene expression profiles following UV exposure in wild-type and SOS-deficient Escherichia coli. Genetics 158: 41-64.

Courcelle J, Donaldson JR, Chow KH, Courcelle CT. 2003. DNA damage-induced replication fork regression and processing in Escherichia coli. Science 299: 1064-1067.

Cox MM. 2001. Recombinational DNA repair of damaged replication forks in Escherichia coli: Questions. Annu Rev Genet 35: 53-82.

Cox MM, Goodman MF, Kreuzer KN, Sherratt DJ, Sandler SJ, Marians KJ. 2000. The importance of repairing stalled replication forks. Nature 404: 37-41.

Cox MM, Keck JL, Battista JR. 2010. Rising from the ashes: DNA repair in Deinococcus radiodurans. PLoS Genet 6: e1000815.

Dalebroux ZD, Swanson MS. 2012. ppGpp: Magic beyond RNA polymerase. Nat Rev Microbiol 10: 203-212.

Daly MJ. 2009. A new perspective on radiation resistance based on Deinococcus radiodurans. Nat Rev Microbiol 7: 237-245. 
Daly MJ, Gaidamakova EK, Matrosova VY, Vasilenko A, Zhai M, Leapman RD, Lai B, Ravel B, Li SMW, Kemner KM. 2007. Protein oxidation implicated as the primary determinant of bacterial radioresistance. PLoS Biol 5: e92.

Daly MJ, Gaidamakova EK, Matrosova VY, Kiang JG, Fukumoto R, Lee DY, Wehr NB, Viteri GA, Berlett BS, Levine RL. 2010. Small-molecule antioxidant proteome-shields in Deinococcus radiodurans. PLoS ONE 5: e12570.

Da Re S, Garnier F, Guérin E, Campoy S, Denis F, Ploy MC 2009. The SOS response promotes qnrB quinolone-resistance determinant expression. EMBO Rep 10: 929-933.

Davidsen T, Tønjum T. 2006. Meningococcal genome dynamics. Nat Rev Microbiol 4: 11-22.

Desai SS, Rajpurohit YS, Misra HS, Deobagkar DN. 2011 Characterization of the role of the RadS/RadR two-component system in the radiation resistance of Deinococcus radiodurans. Microbiology 157: 2974-2982.

Dorer MS, Fero J, Salama NR. 2010. DNA damage triggers genetic exchange in Helicobacter pylori. PLoS Pathog 6: e1001026.

Dorer MS, Sessler TH, Salama NR. 2011. Recombination and DNA repair in Helicobacter pylori. Annu Rev Microbiol 65: 329-348.

Dörr T, Lewis K, Vulić M. 2009. SOS response induces persistence to fluoroquinolones in Escherichia coli. PLoS Genet 5: e1000760.

Dörr T, Vulić M, Lewis K. 2010. Ciprofloxacin causes persister formation by inducing the TisB toxin in Escherichia coli. PLoS Biol 8: e1000317.

Dwyer DJ, Camacho DM, Kohanski MA, Callura JM, Collins JJ. 2012. Antibiotic-induced bacterial cell death exhibits physiological and biochemical hallmarks of apoptosis. Mol Cell 46: 561-572.

Earl AM, Mohundro MM, Mian IS, Battista JR. 2002. The IrrE protein of Deinococcus radiodurans $\mathrm{R} 1$ is a nove regulator of recA expression. J Bacteriol 184: 6216-6224.

Eldin S, Forget AL, Lindenmuth DM, Logan KM, Knight KL. 2000. Mutations in the N-terminal region of RecA that disrupt the stability of free protein oligomers but not RecA-DNA complexes. J Mol Biol 299: 91-101.

Engelberg-Kulka H, Glaser G. 1999. Addiction modules and programmed cell death and antideath in bacterial cultures. Annu Rev Microbiol 53: 43-70.

Engels S, Schweitzer JE, Ludwig C, Bott M, Schaffer S. 2004. clpC and clpP1P2 gene expression in Corynebacterium glutamicum is controlled by a regulatory network involving the transcriptional regulators $\mathrm{ClgR}$ and $\mathrm{HspR}$ as well as the ECF sigma factor $\sigma \mathrm{H}$. Mol Microbiol 52: 285-302.

Erental A, Sharon I, Engelberg-Kulka H. 2012. Two programmed cell death systems in Escherichia coli: An apoptotic-like death is inhibited by the mazEF-mediated death pathway. PLoS Biol 10: el001281.

Erill I, Campoy S, Barbé J. 2007. Aeons of distress: An evolutionary perspective on the bacterial SOS response. FEMS Microbiol Rev 31: 637-656.

Foti JJ, Schienda J, Sutera VA, Lovett ST. 2005. A bacterial G protein-mediated response to replication arrest. Mol Cell 17: $549-560$.

Foti JJ, Devadoss B, Winkler JA, Collins JJ, Walker GC. 2012. Oxidation of the guanine nucleotide pool underlies cell death by bactericidal antibiotics. Science 336: 315-319.
Friedberg EC, Walker GC, Siede W, Wood RD, Schultz RA, Ellenberger T. 2006. DNA repair and mutagenesis. ASM, Washington, DC.

Friedman N, Vardi S, Ronen M, Alon U, Stavans J. 2005. Precise temporal modulation in the response of the SOS DNA repair network in individual bacteria. PLoS Biol 3: e238.

* Fuchs RP, Fujii S. 2013. Translesion DNA synthesis and mutagenesis in prokaryotes. Cold Spring Harb Perspect Biol doi: $10.1101 /$ cshperspect.a012682.

Fujiwara Y, Tatsumi M. 1976. Replicative bypass repair of ultraviolet damage to DNA of mammalian cells: Caffeine sensitive and caffeine resistant mechanisms. Mutat Res 37: $91-110$.

Furukohri A, Goodman MF, Maki H. 2008. A dynamic polymerase exchange with Escherichia coli DNA polymerase IV replacing DNA polymerase III on the sliding clamp. $J$ Biol Chem 283: 11260-11269.

Gabbai CB, Marians KJ. 2010. Recruitment to stalled replication forks of the PriA DNA helicase and replisomeloading activities is essential for survival. DNA Repair (Amst) 9: 202-209.

Gamulin V, Cetkovic H, Ahel I. 2004. Identification of a promoter motif regulating the major DNA damage response mechanism of Mycobacterium tuberculosis. FEMS Microbiol Lett 238: 57-63.

Gerdes K, Maisonneuve E. 2012. Bacterial persistence and toxin-antitoxin loci. Annu Rev Microbiol 66: 103-123.

Gerdes K, Poulsen LK, Thisted T, Nielsen AK, Martinussen J, Andreasen PH. 1990. The hok killer gene family in gramnegative bacteria. New Biol 2: 946-956.

Gerdes K, Christensen SK, Lobner-Olesen A. 2005. Prokaryotic toxin-antitoxin stress response loci. Nat Rev Microbiol 3: 371-382.

Godoy VG, Jarosz DF, Walker FL, Simmons LA, Walker GC. 2006. Y-family DNA polymerases respond to DNA damage-independent inhibition of replication fork progression. $E M B O$ J 25: 868-879.

Goerke C, Köller J, Wolz C. 2006. Ciprofloxacin and trimethoprim cause phage induction and virulence modulation in Staphylococcus aureus. Antimicrob Agents Chemother 50: 171-177.

Golub ET, Panzer HA. 1988. The F factor of Escherichia coli carries a locus of stable plasmid inheritance stm, similar to the parB locus of plasmid RI. Mol Gen Genet 214: $353-$ 357.

Goranov AI, Kuester-Schoeck E, Wang JD, Grossman AD. 2006. Characterization of the global transcriptional responses to different types of DNA damage and disruption of replication in Bacillus subtilis. J Bacteriol 188: $5595-$ 5605.

Gruenig MC, Renzette N, Long E, Chitteni-Pattu S, Inman RB, Cox MM, Sandler SJ. 2008. RecA-mediated SOS induction requires an extended filament conformation but no ATP hydrolysis. Mol Microbiol 69: 1165-1179.

Guerin E, Cambray G, Sanchez-Alberola N, Campoy S, Erill I, Da Re S, Gonzalez-Zorn B, Barbé J, Ploy MC, Mazel D. 2009. The SOS response controls integron recombination. Science 324: 1034.

Gutekunst K, Phunpruch S, Schwarz C, Schuchardt S, Schulz-Friedrich R, Appel J. 2005. LexA regulates the 


\section{K.N. Kreuzer}

bidirectional hydrogenase in the cyanobacterium Synechocystis sp. PCC 6803 as a transcription activator. Mol Microbiol 58: 810-823.

Harris DR, Pollock SV, Wood EA, Goiffon RJ, Klingele AJ, Cabot EL, Schackwitz W, Martin J, Eggington J, Durfee TJ, et al. 2009. Directed evolution of ionizing radiation resistance in Escherichia coli. J Bacteriol 191: 5240-5252.

Hazan R, Sat B, Engelberg-Kulka H. 2004. Escherichia coli mazEF-mediated cell death is triggered by various stressful conditions. J Bacteriol 186: 3663-3669.

Heller RC, Marians KJ. 2006a. Replication fork reactivation downstream of a blocked nascent leading strand. Nature 439: $557-562$

Heller RC, Marians KJ. 2006b. Replisome assembly and the direct restart of stalled replication forks. Nat Rev Mol Cell Biol 7: 932-943.

Higgins NP, Kato K, Strauss B. 1976. A model for replication repair in mammalian cells. J Mol Biol 101: 417-425.

Hocquet D, Llanes C, Thouverez M, Kulasekara HD, Bertrand X, Plésiat P, Mazel D, Miller SI. 2012. Evidence for induction of integron-based antibiotic resistance by the SOS response in a clinical setting. PLoS Pathog 8 e1002778.

Hua Y, Narumi I, Gao G, Tian B, Satoh K, Kitayama S, Shen B. 2003. PprI: A general switch responsible for extreme radioresistance of Deinococcus radiodurans. Biochem Biophys Res Commun 306: 354-360.

Jensen RB, Gerdes K. 1995. Programmed cell death in bacteria: Proteic plasmid stabilization systems. Mol Microbiol 17: $205-210$.

Jochmann N, Kurze AK, Czaja LF, Brinkrolf K, Brune I, Hüser AT, Hansmeier N, Pühler A, Borovok I, Tauch A 2009. Genetic makeup of the Corynebacterium glutamicum LexA regulon deduced from comparative transcriptomics and in vitro DNA band shift assays. Microbiology 155: $1459-1477$.

Kamenšek S, Podlesek Z, Gillor O, Zgur-Bertok D. 2010. Genes regulated by the Escherichia coli SOS repressor LexA exhibit heterogeneous expression. BMC Microbiol 10: 283 .

Kanjee U, Ogata K, Houry WA. 2012. Direct binding targets of the stringent response alarmone (p)ppGpp. Mol Microbiol 85: 1029-1043.

Kawano M, Aravind L, Storz G. 2007. An antisense RNA controls synthesis of an SOS-induced toxin evolved from an antitoxin. Mol Microbiol 64: 738-754.

Kelley WL. 2006. Lex marks the spot: The virulent side of SOS and a closer look at the LexA regulon. Mol Microbiol 62: $1228-1238$.

Keren I, Wu Y, Inocencio J, Mulcahy LR, Lewis K. 2013. Killing by bactericidal antibiotics does not depend on reactive oxygen species. Science 339: 1213-1216.

Khan SR, Kuzminov A. 2012. Replication forks stalled at ultraviolet lesions are rescued via RecA and RuvABC protein-catalyzed disintegration in Escherichia coli. J Biol Chem 287: 6250-6265.

Khil PP, Camerini-Otero RD. 2002. Over 1000 genes are involved in the DNA damage response of Escherichia coli. Mol Microbiol 44: 89-105.
Kohanski MA, Dwyer DJ, Hayete B, Lawrence CA, Collins JJ. 2007. A common mechanism of cellular death induced by bactericidal antibiotics. Cell 130: 797-810.

Kohanski MA, DePristo MA, Collins JJ. 2010. Sublethal antibiotic treatment leads to multidrug resistance via radical-induced mutagenesis. Mol Cell 37: 311-320.

Kreuzer KN. 2005. Interplay between DNA replication and recombination in prokaryotes. Annu Rev Microbiol 59: $43-67$.

Kuzminov A. 1999. Recombinational repair of DNA damage in Escherichia coli and bacteriophage $\lambda$. Microbiol Mol Biol Rev 63: 751-813.

Kuzminov A. 2001. Single-strand interruptions in replicating chromosomes cause double-strand breaks. Proc Natl Acad Sci 98: 8241-8246.

Lacour S, Kolb A, Boris Zehnder AJ, Landini P. 2002. Mechanism of specific recognition of the aidB promoter by $\sigma^{\mathrm{S}}$. RNA polymerase. Biochem Biophys Res Commun 292: 922-930.

Landini P, Hajec LI, Volkert MR. 1994. Structure and transcriptional regulation of the Escherichia coli adaptive response gene aidB. J Bacteriol 176: 6583-6589.

Lewis K. 2010. Persister cells. Annu Rev Microbiol 64: 357372.

Li B, Smith P, Horvath DJ, Romesberg FE, Justice SS. 2010. SOS regulatory elements are essential for UPEC pathogenesis. Microbes Infect 12: 662-668.

Lisby M, Rothstein R. 2009. Choreography of recombination proteins during the DNA damage response. DNA Repair (Amst) 8: 1068-1076.

Lisby M, Rothstein R, Mortensen UH. 2001. Rad52 forms DNA repair and recombination centers during $S$ phase. Proc Natl Acad Sci 98: 8276-8282.

Liu Y, Imlay JA. 2013. Cell death from antibiotics without the involvement of reactive oxygen species. Science 339: $1210-1213$.

Liu J, Marians KJ. 1999. PriA-directed assembly of a primosome on D loop DNA. J Biol Chem 274: 25033-25041.

Liu JI, Xu LW, Sandler SJ, Marians KJ. 1999. Replication fork assembly at recombination intermediates is required for bacterial growth. Proc Natl Acad Sci 96: 3552-3555.

Long DT, Kreuzer KN. 2008. Regression supports two mechanisms of fork processing in phage T4. Proc Natl Acad Sci 105: 6852-6857.

Long DT, Kreuzer KN. 2009. Fork regression is an active helicase-driven pathway in bacteriophage T4. EMBO Rep 10: 394-399.

Lu H, Chen H, Xu G, Shah AM, Hua Y. 2012. DNA binding is essential for PprI function in response to radiation damage in Deinococcus radiodurans. DNA Repair (Amst) 11: $139-145$.

Lusetti SL, Cox MM. 2002. The bacterial RecA protein and the recombinational DNA repair of stalled replication forks. Annu Rev Biochem 71: 71-100.

Macięg M, Kochanowska M, Lyżeń R, Węgrzyn G, Szalewska-Palasz A. 2010. ppGpp inhibits the activity of Escherichia coli DnaG primase. Plasmid 63: 61-67.

Magnuson RD. 2007. Hypothetical functions of toxin-antitoxin systems. J Bacteriol 189: 6089-6092. 
Maiques E, Ubeda C, Campoy S, Salvador N, Lasa I, Novick RP, Barbé J, Penadés JR. 2006. $\beta$-Lactam antibiotics induce the SOS response and horizontal transfer of virulence factors in Staphylococcus aureus. J Bacteriol 188: 2726-2729.

Makarova KS, Omelchenko MV, Gaidamakova EK, Matrosova VY, Vasilenko A, Zhai M, Lapidus A, Copeland A, Kim E, Land M, et al. 2007. Deinococcus geothermalis: The pool of extreme radiation resistance genes shrinks. PLoS ONE 2: e955.

Massoni SC, Leeson MC, Long JE, Gemme K, Mui A, Sandler SJ. 2012. Factors limiting SOS expression in log-phase cells of Escherichia coli. J Bacteriol 194: 53255333.

Mattimore V, Battista JR. 1996. Radioresistance of Deinococcus radiodurans: Functions necessary to survive ionizing radiation are also necessary to survive prolonged desiccation. J Bacteriol 178: 633-637.

McCool JD, Long E, Petrosino JF, Sandler HA, Rosenberg SM, Sandler SJ. 2004. Measurement of SOS expression in individual Escherichia coli K-12 cells using fluorescence microscopy. Mol Microbiol 53: 1343-1357.

McGlynn P, Lloyd RG. 2002. Recombinational repair and restart of damaged replication forks. Nat Rev Mol Cell Biol 3: 859-870.

McGlynn P, Savery NJ, Dillingham MS. 2012. The conflict between DNA replication and transcription. Mol Microbiol 85: 12-20.

McGrath BM, O'Halloran JA, Pembroke JT. 2005. Pre-exposure to UV irradiation increases the transfer frequency of the IncJ conjugative transposon-like elements R391, R392, R705, R706, R997 and pMERPH and is recA ${ }^{+}$dependent. FEMS Microbiol Lett 243: 461-465.

Merrikh H, Ferrazzoli AE, Bougdour A, Olivier-Mason A, Lovett ST. 2009. A DNA damage response in Escherichia coli involving the alternative sigma factor, RpoS. Proc Natl Acad Sci 106: 611-616.

Michel B. 2000. Replication fork arrest and DNA recombination. Trends Biochem Sci 25: 173-178.

Michel B. 2005. After 30 years of study, the bacterial SOS response still surprises us. PLoS Biol 3: e255.

Michel B, Ehrlich SD, Uzest M. 1997. DNA double-strand breaks caused by replication arrest. EMBO J 16: 430-438.

Michel B, Boubakri H, Baharoglu Z, LeMasson M, Lestini R. 2007. Recombination proteins and rescue of arrested replication forks. DNA Repair (Amst) 6: 967-980.

Miller C, Ingmer H, Thomsen LE, Skarstad K, Cohen SN. 2003. DpiA binding to the replication origin of Escherichia coli plasmids and chromosomes destabilizes plasmid inheritance and induces the bacterial SOS response. J Bacteriol 185: 6025-6031.

Miller C, Thomsen LE, Gaggero C, Mosseri R, Ingmer H, Cohen SN. 2004. SOS response induction by $\beta$-lactams and bacterial defense against antibiotic lethality. Science 305: 1629-1631.

Modell JW, Hopkins AC, Laub MT. 2011. A DNA damage checkpoint in Caulobacter crescentus inhibits cell division through a direct interaction with FtsW. Genes Dev 25: $1328-1343$.
Nariya H, Inouye M. 2008. MazF, an mRNA interferase, mediates programmed cell death during multicellular Myxococcus development. Cell 132: 55-66.

Narumi I, Satoh K, Kikuchi M, Funayama T, Yanagisawa T, Kobayashi Y, Watanabe H, Yamamoto K. 2001. The LexA protein from Deinococcus radiodurans is not involved in RecA induction following $\gamma$ irradiation. J Bacteriol 183: 6951-6956.

Opperman T, Murli S, Smith BT, Walker GC. 1999. A model for a umuDC-dependent prokaryotic DNA damage checkpoint. Proc Natl Acad Sci 96: 9218-9223.

Pedersen K, Christensen SK, Gerdes K. 2002. Rapid induction and reversal of a bacteriostatic condition by controlled expression of toxins and antitoxins. Mol Microbiol 45: 501-510.

Pennington JM, Rosenberg SM. 2007. Spontaneous DNA breakage in single living Escherichia coli cells. Nat Genet 39: $797-802$.

Persky NS, Ferullo DJ, Cooper DL, Moore HR, Lovett ST. 2009. The ObgE/CgtA GTPase influences the stringent response to amino acid starvation in Escherichia coli. Mol Microbiol 73: 253-266.

Petrova V, Chitteni-Pattu S, Drees JC, Inman RB, Cox MM. 2009. An SOS inhibitor that binds to free RecA protein: The PsiB protein. Mol Cell 36: 121-130.

Pomerantz RT, O’Donnell M. 2010. Polymerase trafficking: A role for transcription factors in preventing replication fork arrest. Transcr 1: 136-139.

Potrykus K, Cashel M. 2008. (p)ppGpp: Still magical? Annu Rev Microbiol 62: 35-51.

Prudhomme M, Attaiech L, Sanchez G, Martin B, Claverys JP. 2006. Antibiotic stress induces genetic transformability in the human pathogen Streptococcus pneumoniae. Science 313: 89-92.

Quinones M, Kimsey HH, Waldor MK. 2005. LexA cleavage is required for CTX prophage induction. Mol Cell 17: 291-300.

Rajpurohit YS, Misra HS. 2010. Characterization of a DNA damage-inducible membrane protein kinase from Deinococcus radiodurans and its role in bacterial radioresistance and DNA strand break repair. Mol Microbiol 77: $1470-1482$.

Rand L, Hinds J, Springer B, Sander P, Buxton RS, Davis EO. 2003. The majority of inducible DNA repair genes in Mycobacterium tuberculosis are induced independently of RecA. Mol Microbiol 50: 1031-1042.

Renzette N, Gumlaw N, Nordman JT, Krieger M, Yeh SP, Long E, Centore R, Boonsombat R, Sandler SJ. 2005. Localization of RecA in Escherichia coli K-12 using RecA-GFP. Mol Microbiol 57: 1074-1085.

Rippa V, Amoresano A, Esposito C, Landini P, Volkert M, Duilio A. 2010. Specific DNA binding and regulation of its own expression by the AidB protein in Escherichia coli. J Bacteriol 192: 6136-6142.

Rippa V, Duilio A, di Pasquale P, Amoresano A, Landini P, Volkert MR. 2011. Preferential DNA damage prevention by the E. coli AidB gene: A new mechanism for the protection of specific genes. DNA Repair (Amst) 10: 934941.

Rohankhedkar MS, Mulrooney SB, Wedemeyer WJ, Hausinger RP. 2006. The AidB component of the Escherichia 
K.N. Kreuzer

coli adaptive response to alkylating agents is a flavin-containing, DNA-binding protein. J Bacteriol 188: 223-230.

Sat B, Hazan R, Fisher T, Khaner H, Glaser G, EngelbergKulka H. 2001. Programmed cell death in Escherichia coli: Some antibiotics can trigger mazEF lethality. J Bacteriol 183: 2041-2045.

Satoh K, Ohba H, Sghaier H, Narumi I. 2006. Down-regulation of radioresistance by LexA2 in Deinococcus radiodurans. Microbiology 152: 3217-3226.

Schook POP, Stohl EA, Criss AK, Seifert HS. 2011. The DNA-binding activity of the Neisseria gonorrhoeae LexA orthologue NG1427 is modulated by oxidation. Mol Microbiol 79: 846-860.

Seigneur M, Bidnenko V, Ehrlich SD, Michel B. 1998. RuvAB acts at arrested replication forks. Cell 95: 419-430.

Shimoni Y, Altuvia S, Margalit H, Biham O. 2009. Stochastic analysis of the SOS response in Escherichia coli. PLoS ONE 4: e5363.

Simmons LA, Grossman AD, Walker GC. 2007. Replication is required for the RecA localization response to DNA damage in Bacillus subtilis. Proc Natl Acad Sci 104: $1360-1365$.

Simmons LA, Goranov AI, Kobayashi H, Davies BW, Yuan DS, Grossman AD, Walker GC. 2009. Comparison of responses to double-strand breaks between Escherichia coli and Bacillus subtilis reveals different requirements for SOS induction. J Bacteriol 191: 1152-1161.

Singletary LA, Gibson JL, Tanner EJ, McKenzie GJ, Lee PL, Gonzalez C, Rosenberg SM. 2009. An SOS-regulated type 2 toxin-antitoxin system. J Bacteriol 191: 7456-7465.

Sitkiewicz I, Green NM, Guo N, Mereghetti L, Musser JM. 2011. Lateral gene transfer of streptococcal ICE element $\mathrm{RD} 2$ (region of difference 2) encoding secreted proteins. BMC Microbiol 11: 65.

Slade D, Radman M. 2011. Oxidative stress resistance in Deinococcus radiodurans. Microbiol Mol Biol Rev 75: 133-191.

Slade D, Lindner AB, Paul G, Radman M. 2009. Recombination and replication in DNA repair of heavily irradiated Deinococcus radiodurans. Cell 136: 1044-1055.

Smollett KL, Smith KM, Kahramanoglou C, Arnvig KB, Buxton RS, Davis EO. 2012. Global analysis of the regulon of the transcriptional repressor LexA, a key component of SOS response in Mycobacterium tuberculosis. $J$ Biol Chem 287: 22004-22014.

Srivatsan A, Wang JD. 2008. Control of bacterial transcription, translation and replication by (p)ppGpp. Curr Opin Microbiol 11: 100-105.

Sutton MD, Walker GC. 2001. umuDC-mediated cold sensitivity is a manifestation of functions of the UmuD2C complex involved in a DNA damage checkpoint control. $J$ Bacteriol 183: 1215-1224.

Tanaka M, Earl AM, Howell HA, Park MJ, Eisen JA, Peterson SN, Battista JR. 2004. Analysis of Deinococcus radiodurans's transcriptional response to ionizing radiation and desiccation reveals novel proteins that contribute to extreme radioresistance. Genetics 168: 21-33.

Tapias A, Fernández S, Alonso JC, Barbé J. 2002. Rhodobacter sphaeroides LexA has dual activity: Optimising and repressing recA gene transcription. Nucleic Acids Res 30: 1539-1546.
Tormo M, Ferrer MD, Maiques E, Úbeda C, Selva L, Lasa Calvete JJ, Novick RP, Penadés JR. 2008. Staphylococcus aureus pathogenicity island DNA is packaged in particles composed of phage proteins. J Bacteriol 190: 2434-2440.

Tsilibaris V, Maenhaut-Michel G, Mine N, Van Melderen L. 2007. What is the benefit to Escherichia coli of having multiple toxin-antitoxin systems in its genome? J Bacteriol 189: 6101-6108.

Ubeda C, Maiques E, Knecht E, Lasa I, Novick RP, Penadés JR. 2005. Antibiotic-induced SOS response promotes horizontal dissemination of pathogenicity island-encoded virulence factors in staphylococci. Mol Microbiol 56: 836-844.

Ubeda C, Barry P, Penadés JR, Novick RP. 2007. A pathogenicity island replicon in Staphylococcus aureus replicates as an unstable plasmid. Proc Natl Acad Sci 104: 1418214188.

Uchida K, Furukohri A, Shinozaki Y, Mori T, Ogawara D, Kanaya S, Nohmi T, Maki H, Akiyama M. 2008. Overproduction of Escherichia coli DNA polymerase DinB (Pol IV) inhibits replication fork progression and is lethal. Mol Microbiol 70: 608-622.

Unoson C, Wagner EGH. 2008. A small SOS-induced toxin is targeted against the inner membrane in Escherichia coli. Mol Microbiol 70: 258-270.

Ventura M, Zhang Z, Cronin M, Canchaya C, Kenny JG, Fitzgerald GF, Van Sinderen D. 2005. The ClgR protein regulates transcription of the $c l p P$ operon in Bifidobacterium breve UCC 2003. J Bacteriol 187: 8411-8426.

Volkert MR, Hajec LI, Matijasevic Z, Fang FC, Prince R. 1994. Induction of the Escherichia coli aidB gene under oxygen-limiting conditions requires a functional rpoS (katF) gene. J Bacteriol 176: 7638-7645.

Wade JT, Reppas NB, Church GM, Struhl K. 2005. Genomic analysis of LexA binding reveals the permissive nature of the Escherichia coli genome and identifies unconventional target sites. Genes Dev 19: 2619-2630.

Waldor MK, Friedman DI. 2005. Phage regulatory circuits and virulence gene expression. Curr Opin Microbiol 8: 459-465.

Wang JD, Sanders GM, Grossman AD. 2007. Nutritional control of elongation of DNA replication by (p)ppGpp. Cell 128: 865-875.

Wang L, Xu G, Chen H, Zhao Y, Xu N, Tian B, Hua Y. 2008. DrRRA: A novel response regulator essential for the extreme radioresistance of Deinococcus radiodurans. Mol Microbiol 67: 1211-1222.

Wang M, Jacoby GA, Mills DM, Hooper DC. 2009. SOS regulation of qnrB expression. Antimicrob Agents Chemother 53: 821-823.

Wang Y, Huang Y, Xue C, He Y, He ZG. 2011. ClpR proteinlike regulator specifically recognizes RecA protein-independent promoter motif and broadly regulates expression of DNA damage-inducible genes in mycobacteria. J Biol Chem 286: 31159-31167.

Wozniak RAF, Waldor MK. 2010. Integrative and conjugative elements: Mosaic mobile genetic elements enabling dynamic lateral gene flow. Nat Rev Microbiol 8: $552-563$. 
DNA Damage Responses in Prokaryotes

Xu L, Marians KJ. 2003. PriA mediates DNA replication pathway choice at recombination intermediates. $\mathrm{Mol}$ Cell 11: 817-826.

Yamaguchi Y, Park JH, Inouye M. 2011. Toxin-antitoxin systems in bacteria and archaea. Annu Rev Genet 45: 61-79.

Yeeles JT, Marians KJ. 2011. The Escherichia coli replisome is inherently DNA damage tolerant. Science 334: 235 238.

Zahradka K, Slade D, Bailone A, Sommer S, Averbeck D, Petranovic M, Lindner AB, Radman M. 2006. Reassembly of shattered chromosomes in Deinococcus radiodurans. Nature 443: 569-573.
Zhang Y, Yamaguchi Y, Inouye M. 2009. Characterization of YafO, an Escherichia coli toxin. J Biol Chem 284: 2552225531.

Zhao G, Ceci P, Ilari A, Giangiacomo L, Laue TM, Chiancone E, Chasteen ND. 2002. Iron and hydrogen peroxide detoxification properties of DNA-binding protein from starved cells A ferritin-like DNA-binding protein of Escherichia coli. J Biol Chem 277: 27689-27696.

Zheng M, Wang X, Templeton LJ, Smulski DR, LaRossa RA, Storz G. 2001. DNA microarray-mediated transcriptional profiling of the Escherichia coli response to hydrogen peroxide. J Bacteriol 183: 4562-4570. 


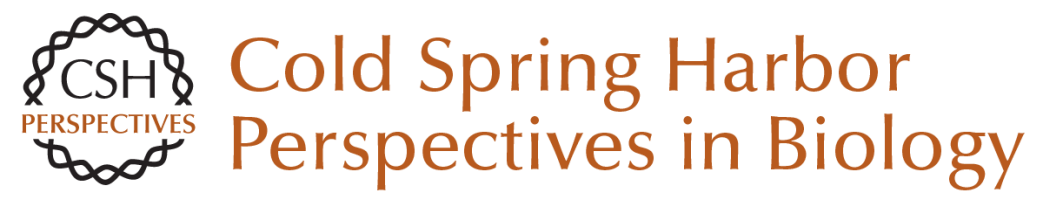

\section{DNA Damage Responses in Prokaryotes: Regulating Gene Expression, Modulating Growth Patterns, and Manipulating Replication Forks}

Kenneth N. Kreuzer

Cold Spring Harb Perspect Biol 2013; doi: 10.1101/cshperspect.a012674 originally published online October 4, 2013

Subject Collection DNA Repair, Mutagenesis, and Other Responses to DNA Damage

DNA Repair by Reversal of DNA Damage Chengqi Yi and Chuan He

Replicating Damaged DNA in Eukaryotes Nimrat Chatterjee and Wolfram Siede

DNA Damage Sensing by the ATM and ATR

Kinases

Alexandre Maréchal and Lee Zou

Repair of Strand Breaks by Homologous

Recombination

Maria Jasin and Rodney Rothstein

Advances in Understanding the Complex Mechanisms of DNA Interstrand Cross-Link

Repair

Cheryl Clauson, Orlando D. Schärer and Laura Niedernhofer

Ancient DNA Damage

Jesse Dabney, Matthias Meyer and Svante Pääbo

DNA Damage Response: Three Levels of DNA

Repair Regulation

Bianca M. Sirbu and David Cortez
DNA Repair by Reversal of DNA Damage Chengqi Yi and Chuan He

Translesion DNA Synthesis and Mutagenesis in Prokaryotes Robert P. Fuchs and Shingo Fujii

Nucleosome Dynamics as Modular Systems that Integrate DNA Damage and Repair Craig L. Peterson and Genevieve Almouzni

DNA Damage Responses in Prokaryotes:

Regulating Gene Expression, Modulating Growth

Patterns, and Manipulating Replication Forks Kenneth N. Kreuzer

Nucleotide Excision Repair in Eukaryotes Orlando D. Schärer

Biology of Extreme Radiation Resistance: The

Way of Deinococcus radiodurans Anita Krisko and Miroslav Radman

Mammalian Transcription-Coupled Excision

Repair

Wim Vermeulen and Maria Fousteri

For additional articles in this collection, see http://cshperspectives.cshlp.org/cgi/collection/

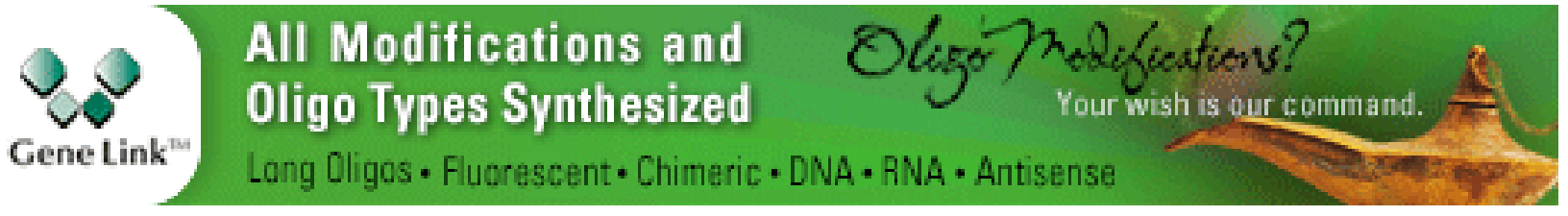

Copyright @ 2013 Cold Spring Harbor Laboratory Press; all rights reserved 
Alternative Excision Repair Pathways Akira Yasui
DNA Repair at Telomeres: Keeping the Ends

Intact

Christopher J. Webb, Yun Wu and Virginia A. Zakian

For additional articles in this collection, see http://cshperspectives.cshlp.org/cgi/collection/

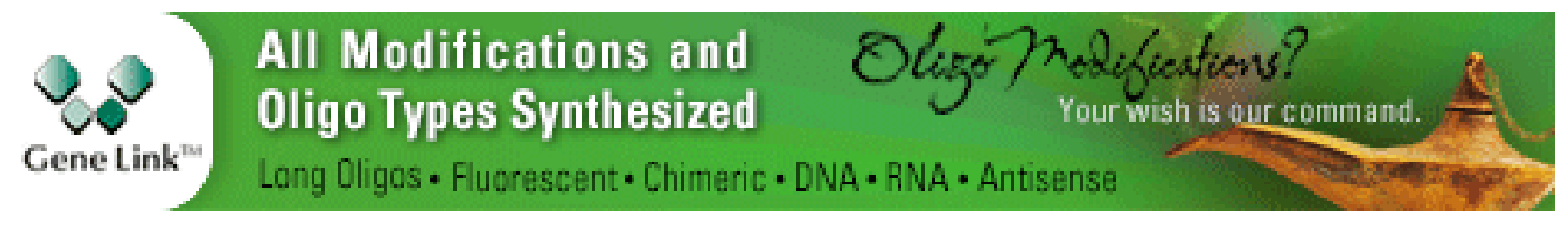

Copyright @ 2013 Cold Spring Harbor Laboratory Press; all rights reserved 